\title{
Bolhas e Crises Financeiras: o crescimento fragilizado da economia norte-americana a partir da década de $90^{*}$
}

Tiago Ferreira**

Resumo: O presente trabalho procura estudar certos aspectos relacionados às flutuações da economia norte-americana nas últimas duas décadas, caracterizadas por duas fases de crescimento contínuo seguidos de crises financeiras. Nessas fases, as principais forças expansionistas foram desequilíbrios financeiros que fomentaram a criação de bolhas de ativos. Busca-se também nesse trabalho apontar bases teóricas, derivadas das proposições do economista Hyman Minsky, para a interpretação desse processo e examinar a dinâmica desses desequilíbrios, em especial seus determinantes.

Palavras-Chave: Economia Norte-Americana, Crises Financeiras, Bolhas Especulativas.

Abstract: This paper aims to study certain aspects of the business cycles of the U.S economy on the last two decades. During this period, there were two long phases of continuous growth followed by financial crisis. The major expansionary forces were financial unbalances that generated asset bubbles. To accomplish that, this work presents the Minskyan theoretical bases as a guide to the analysis of the dynamics of these unbalances, especially its determinants.

Keywords: U.S. Economy, Financial Crisis, Assets Bubbles.

JEL Classification: E12; E32; O11; O40.

\section{Introdução}

A economia norte-americana apresentou nas últimas duas décadas dois ciclos com crescimentos longos, abortados por crises financeiras que exigiram intervenções nos mercados a fim de se evitar o agravamento das recessões. Em comum, às duas etapas, o gasto privado como a principal força motriz da economia. Esses gastos foram alimentados por fortes desequilíbrios nas estruturas financeiras. $\mathrm{Na}$

* O autor agradece os comentários realizados por ocasião do I Encontro Internacional da Sociedade Brasileira de Economia Keynesiana, especialmente as observações de Gilberto Tadeu Lima. Eventuais falhas remanescentes são de resposabilidade do autor.

* Economista do BNDES e pós-graduando em economia pelo IPE/FEA/USP. E-mail: tiagotf@usp.br 
primeira fase - 1991-2000 - os desequilíbrios estavam presentes nas estruturas financeiras do setor externo e do setor privado enquanto na segunda - 2001-2007 - eles foram observados nas estruturas das famílias, do setor externo e do governo.

Gráfico 1. Contribuição do Componente para a Variação Percentual do PNB

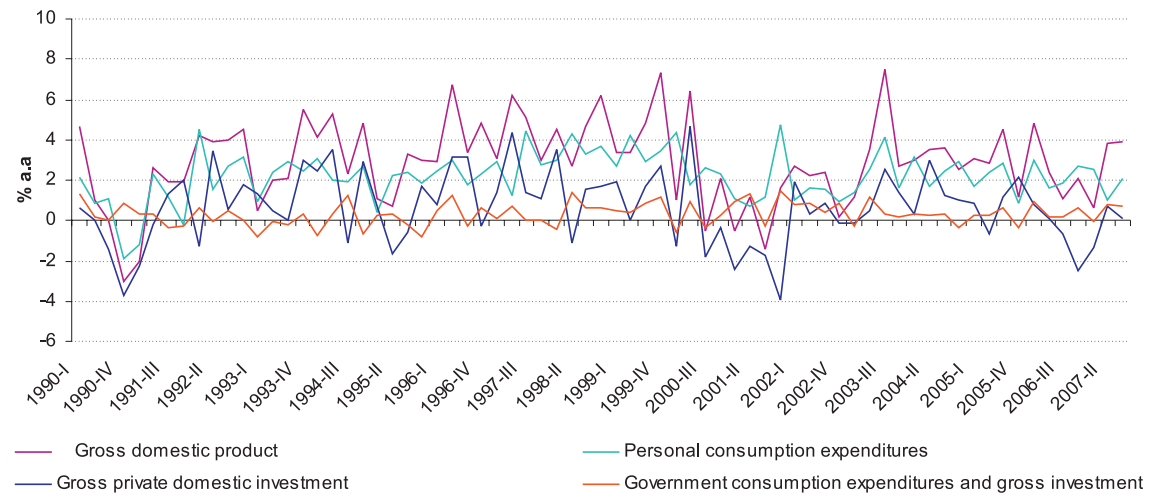

Fonte: NIPA.

Os economistas, em geral, preocupam-se com a sustentabilidade dos déficits fiscais e externos, mas dão pouca atenção aos efeitos do endividamento privado. Ao comprometer parte da renda futura, o acúmulo de débitos torna as unidades econômicas vulneráveis a eventos que reduzam a renda efetivamente auferida ou que aumentem os serviços financeiros. Nesses casos, a não eclosão de uma crise passa a depender do provimento de crédito às unidades. Ao longo das etapas de crescimento, a confiança aumentou a tolerância ao risco e as estruturas financeiras foram fragilizadas. Esse movimento exacerba a tensão dos mercados, tornando as expectativas mais voláteis, e qualquer evento pode desencadear uma recessão.

Além de acompanhar a evolução dos processos e apresentar as bases teóricas para sua interpretação, o conhecimento dos fatores que incentivaram essa maior tomada de débitos é fundamental para a melhor compreensão dos eventos. 


\section{A Economia Norte-Americana após 1991}

\section{$2.11991-2000$}

A partir da retomada do crescimento no segundo trimestre de 1991, a economia norte-americana entrou em um período de expansão, o mais longo do pós-guerra. O produto nacional bruto real cresceu por 37 trimestres consecutivos até o segundo trimestre de 2000. Apesar de longo, o crescimento não teve a mesma intensidade daquele observado nas décadas de 50 e 60. Enquanto a taxa média de crescimento real anual entre 1992 e 1999 foi de 3,67\%, nas décadas de 50 e 60 ela foi $4,15 \%$ e $4,44 \%$, respectivamente.

O crescimento foi acompanhado pelo aumento da produtividade e inflação baixa. O ápice foi o ano de 1999 quando o produto real cresceu 4,45\%. A taxa de desemprego caiu de 6,8\% em 1991 para $4 \%$ em 2000. Entre 1992 e 2000, o crescimento médio da produtividade foi de $4,2 \%$ ao ano.

O dinamismo da economia ficou a cargo dos setores de tecnologia, mídia e telecomunicações, basicamente serviços de informação. Eles passaram a formar a chamada Nova Economia, de base distinta à tradicional alicerçada em bens. Acreditava-se que esses setores, por estarem sujeitos a retornos crescentes e apresentarem altas taxas de inovação, permitiriam o crescimento econômico por tempo ilimitado. Os investimentos realizados no período ficaram concentrados nesses setores e foram vistos como responsáveis por um crescimento que não gerava pressões inflacionárias, possibilitando a manutenção de uma política monetária acomodatícia, visão defendida por Greenspan (2000). Adicionalmente, ele coloca o papel dos superávits fiscais na contenção do excesso de demanda.

Alguns críticos defendem que a mania de ativos fez seus valores crescerem acima da inflação, permitindo um ciclo de investimento mais longo que o usual, estendendo uma etapa de um ciclo que parecia eterna para os defensores do modelo da Nova Economia. Assim, muitas qualificações devem ser feitas ao processo. Com certeza existiram ganhos de produtividade que, no entanto, não foram tão extensos quanto imaginados anteriormente, e a queda no valor dos ativos mostra que muitas condições eram transitórias e não fundamentadas.

E foram justamente os ajustes e as correções de inventário, avaliação dos ativos, que iniciaram a queda no valor das ações em 2000. As empresas do setor de tecnologia da informação tiveram seus potenciais superavaliados. O índice da Nasdaq, que engloba boa 
parte das empresas de tecnologia, pulou de aproximadamente 2000 pontos em 1998 para mais de 5000 pontos no começo de 2000 . O lançamento primário de ações da Netscape, empresa fornecedora de navegadores de internet, realizado no dia 9 de agosto de 1995 ilustra bem essa situação e é considerado por muitos o evento inicial dessa mania. ${ }^{1}$ Apesar de líder em seu setor, os produtos da empresa eram fornecidos gratuitamente e, baseado apenas no potencial de comercialização, as ações subiram de US\$ 28 para US\$71. Pastor e Veronesi (2006) defendem que a valorização das ações da Nasdaq está associada, em grande medida, à grande incerteza existente no mercado de tecnologia no final da década de 90, expressa pela grande volatilidade do índice de ações. As expectativas em relação aos usos da tecnologia criada foram excessivamente otimistas. Os consumidores, em grande parte por causa de hábitos, não incorporaram e utilizaram todo o potencial das tecnologias lançadas no mercado. Esperava-se, por exemplo, uma grande explosão nas vendas de produtos pela internet, mas questões culturais e receios sobre a segurança das transações frearam o desenvolvimento da prática. Em geral, os resultados esperados não se materializaram e muitas empresas só apresentaram prejuízos. A queda de rentabilidade das empresas da Nasdaq no biênio 2000-2001 resultou em revisões das expectativas. A falta de fundamentação para o elevado crescimento do valor das ações caracterizou a formação da bolha, tese defendida por Shiller (2001).

A economia cresceu muito em 1999, apesar dos receios surgidos após a crise da Rússia, e dava sinais de superaquecimento. O FED apertou a política monetária esperando reduzir o ritmo do crescimento de forma moderada, o soft landing. Entretanto, a alta do preço do barril de petróleo amplificou seus efeitos e, no cenário de estouro da bolha de ações, a taxa de crescimento caiu rapidamente.

O primeiro sintoma de crise foi a acumulação de estoques. As empresas responderam com cortes de investimento e funcionários. A taxa de desemprego, que iniciara o ano de 2001 próxima à $4 \%$, terminou na casa dos 5,5\% no último trimestre, um crescimento de $40 \%$ em relação à observada em dezembro de 2000. Já o investimento, medido em termos reais, esteve em queda durante todo o ano de 2001. O NBER declarou em 26 de novembro de 2001 que a economia norte-americana entrara em recessão em março daquele ano. Um desdobramento de uma crise eclodida um ano antes quando o mercado de ações entrou em colapso, o estouro da bolha da Nasdaq.

1 Greenspan (2007) apresenta esses eventos. 


\section{$2.22001-2007$}

O FED iniciou o processo de queda de juros para atacar a nascente recessão em 2001. Uma conseqüência foi o direcionamento de capitais para o setor imobiliário, considerado uma alternativa segura em tempos de grande volatilidade nas bolsas de valores. O crescimento do setor imobiliário norte-americano esteve intimamente relacionado à expansão do crédito, provocada pelos baixos juros e inovações financeiras, especialmente a securitização e o desenvolvimento de mercados secundários líquidos para esses títulos. Essa expansão do crédito é expressa pelos valores de originação de hipotecas que cresceram de US $\$ 2$ trilhões em 2002 para US $\$ 3$ trilhões em 2006, passando por um pico de US\$ 4 trilhões em 2004.

No quarto trimestre de 2001 a economia retoma o processo de crescimento. Desde então, são 24 trimestres de crescimento contínuo, o quarto mais longo do pós-guerra. O crescimento médio anual do produto real entre 2002 e 2006 foi de $2,74 \%$, inferior àquele observado na década de 90.

As instituições financeiras adotaram a securitização para expandir o crédito. ${ }^{2}$ Os créditos imobiliários passaram a constituir títulos, Collatereralized Debt Obligations - CDO, negociados nos mercados e avaliados por agências de risco. Os CDOs são compostos por diferentes classes de créditos, oferecendo opções adequadas à propensão ao risco de cada investidor. A securitização ao difundir o risco no mercado facilita a captação e aumenta a tolerância ao risco por parte dos originadores das operações. Esses títulos são vendidos em mercados globais e a concessão de crédito torna-se independente da poupança interna.

Logo, os clientes com melhores estruturas financeiras foram atendidos e os bancos passaram assumir maior risco, reduzindo as exigências para a concessão de novos empréstimos. Além de permitir a expansão das operações, a nova base de crédito significava uma maior rentabilidade, fundamental tendo em vista as baixas taxas de juros praticadas na economia norte-americana. Essas hipotecas de menor qualidade são chamadas de subprime. As hipotecas do tipo ARM exemplificam essa situação. Elas oferecem taxas de juros extremamente baixas nos dois ou três anos iniciais, mas depois essas taxas enfrentam fortes elevações. A securitização, as modernas ferramentas de gestão financeira e a atuação das agencias de rating

2 Kregel (2007) e Wray (2007) discutem detalhadamente essas mudanças.

Ferreira, T. Bolhas e crises financeiras: o crescimento fragilizado da economia... 
conferiram uma sensação de segurança aos investidores que aceitaram uma maior exposição ao risco.

Tabela 1. Composição de Hipotecas

\begin{tabular}{|c|c|c|c|c|c|}
\hline & $\begin{array}{c}\text { Originação Total de } \\
\text { Hipotecas - US\$ } \\
\text { bilhões }\end{array}$ & $\begin{array}{c}\text { Originação de } \\
\text { Subprime-US } \\
\text { bilhões }\end{array}$ & $\begin{array}{c}\text { Parcela do Subprime } \\
\text { no Total de } \\
\text { Originaçóes - \% do } \\
\text { valor }\end{array}$ & $\begin{array}{c}\text { Hipotecas Subprime } \\
\text { Securitizadas - US\$ } \\
\text { bilhões }\end{array}$ & $\begin{array}{c}\text { Percentual de } \\
\text { Subprime } \\
\text { Securitizada - \% do } \\
\text { valor }\end{array}$ \\
\hline 2001 & 2215 & 190 & 8,6 & 95 & 50,4 \\
\hline 2002 & 2885 & 231 & 8 & 121 & 52,7 \\
\hline 2003 & 3945 & 335 & 8,5 & 202 & 60,5 \\
\hline 2004 & 2920 & 540 & 18,5 & 401 & 74,3 \\
\hline 2005 & 3120 & 625 & 20 & 507 & 81,2 \\
\hline 2006 & 2980 & 600 & 20,1 & 483 & 80,5 \\
\hline
\end{tabular}

Fonte: Wray (2007).

Esse aumento do crédito impulsionou as operações no setor imobiliário e redundou no aumento dos preços das construções. Essa apreciação dos ativos tornava o investimento mais atrativo e estimulou a tomada de empréstimos. O estoque de construções, avaliado em menos de US\$ 10 trilhões em 1997, atingiu a marca de US\$ 20 trilhões em 2005. Dessa vez, a bolha foi no mercado imobiliário.

A política fiscal também desempenhou papel-chave na retomada do crescimento. Mais expansionista, ela foi ancorada em dois pilares: redução de impostos e aumento de gastos. Essa política reverteu os crescentes superávits do final da década de 90 em déficits fiscais. O corte de impostos, um dos principais pontos da campanha eleitoral do presidente Bush, foi concentrado nas camadas mais altas de ren$\mathrm{da}$, reduzindo seu potencial sobre o crescimento do produto. O aumento dos gastos públicos foi liderado pelo fortalecimento da estrutura de defesa nacional na esteira dos atentados de 11 de setembro. O gasto público, em termos reais, cresceu 4,4\% em 2002 em relação a 2001 enquanto o gasto em defesa nacional cresceu 7,4\%.

Em 2006, aparecem os primeiros dados preocupantes, indicando uma expansão imprudente do crédito em direção a credores com estruturas financeiras incompatíveis às obrigações assumidas. O clima de tensão e insegurança reduziu o volume de operações. Faltava o evento que traria a crise. E ele aconteceu no dia 9 de agosto de 2007 quando banco francês BNP Paribas anunciou o congelamento de saques em três fundos investimentos com elevada participação de CDOs gerados a partir de operações imobiliárias. O reflexo imediato foi a contenção do crédito, agravando situação de alguns devedores, dependentes de novos empréstimos para pagar os serviços da dívida contraída. Várias medidas foram tomadas pelos bancos centrais dos países desenvolvidos para injetar maior liquidez 
nos mercados, o FED retomou a queda de juros e o tesouro norteamericano negociou com as instituições financeiras um pacote de medidas alterando regras e congelando os juros de algumas hipotecas. Esse plano, anunciado em 6 de dezembro, foi insuficiente para combater a crise que já tinha se generalizado na economia. A recessão cada vez mais iminente levou o governo a apresentar em 18 de janeiro de 2008 um novo plano que contou com a aprovação de Ben Bernanke, chairman do FED. As medidas representaram o começo de um conjunto de ações dos principais bancos centrais mundiais e do Tesouro Norte-Americano na tentativa de debelar a crise, com insucesso até o momento em que este artigo foi escrito.

\section{Endividamento e a Fragilidade}

A maior força expansionista nos dois ciclos de crescimento apresentados na seção anterior foram os níveis elevados de gastos privados, alimentados pelo endividamento. O crédito dirige os movimentos da moeda que tem seu nível determinado pela demanda. Ela responde a mudanças no comportamento das unidades econômicas privadas sendo, portanto, endógena em economias monetárias de produção. Além do crédito, a moeda pode variar em decorrência de medidas de política econômica - monetária e fiscal - e do saldo de transações externas conforme exposto por Arestis (1992). Nessa visão, o governo não consegue controlar o estoque de moeda já que suas medidas podem ser anuladas pelo mercado de crédito. Essa expansão é possibilitada pelas inovações financeiras - novos instrumentos financeiros, práticas de gestão ou novos mercados - das instituições financeiras em busca de maior lucratividade. A importância desse canal de criação de moeda varia conforme o grau de desenvolvimento do sistema financeiro.

Por mais que as inovações financeiras permitam o crescimento do endividamento e melhorem a gestão financeira, esse processo encontra limites na própria vulnerabilidade que engendra na economia. Os episódios descritos na seção anterior são eventos clássicos de crises financeiras, caracterizadas com precisão por Hyman Minsky $\left(1919\right.$ - 1996). ${ }^{3}$ Ele formulou a Hipótese da Instabilidade Financeira, segundo a qual as economias capitalistas têm dois regimes de financiamento: um robusto e outro frágil. Ainda segundo essa hipótese, há uma tendência natural de migração do regime robusto para o frágil.

3 Minsky (1982), Dymsky $\mathcal{E}$ Pollin (1992) e Mehrling (1999) consolidam a visão do autor.

Ferreira, T. Bolhas e crises financeiras: o crescimento fragilizado da economia... 
A robustez e a fragilidade estão relacionadas às estruturas financeiras das unidades econômicas. Na estrutura hedge finance as receitas esperadas superam as obrigações a cada período. Na especulativa, a unidade precisará em alguns momentos de empréstimos para cobrir juros, enquanto os empréstimos das unidades ponzi, em alguns instantes, serão superiores à necessidade de juros. Uma alta proporção de unidades com arranjos do tipo hedge finance caracteriza um arranjo robusto. Enquanto em um arranjo frágil, há uma baixa proporção de arranjos do tipo hedge e as unidades têm pouca margem de manobra face aos eventos futuros, por conta do alto grau de comprometimento dos seus fluxos financeiros.

Suporemos inicialmente uma economia com um padrão de financiamento robusto e em crescimento para a realização de uma descrição estilizada de um ciclo minskyano típico. O bom cenário valida os compromissos e premia as estruturas mais alavancadas. A sensação de confiança leva ao relaxamento das margens de segurança e tanto o sistema financeiro quanto as unidades passam a aceitar uma maior exposição ao risco. A estrutura financeira muda na direção de uma maior alavancagem. Os preços dos ativos e o investimento sobem, o resultado positivo valida as posições financeiras das unidades. A proporção de unidades do tipo hedge cai em favor do aumento das unidades com arranjos financeiros dos tipos especulativo e ponzi, ampliando a vulnerabilidade da economia já que as unidades dependem do refinanciamento contínuo. Um evento que coloque dúvidas acerca da capacidade de pagamento futuro dos compromissos assumidos pelas unidades reverte as expectativas, e o sistema financeiro corta novos empréstimos. A queda na receita efetivamente auferida, inferior à esperada, transforma unidades hedge em especulativa e ponzi, e há forte risco de insolvência. Os condutores da política econômica respondem baixando os juros e injetando liquidez que muitas vezes não chega aos destinatários.

Essa descrição do ciclo está intimamente relacionada ao processo de formação de bolhas especulativas descrito por Shiller (2001, p. 3):

The essence of a speculative bubble is a sort of feedback, from price increases, to increased investor enthusiasm, to increased demand, and hence further price increases. The high demand for the asset is generated by the public memory of high past returns, and the optimism those high returns generate for the future. The feedback can amplify positive forces affecting the market, making the market reach higher levels than it would if it were responding only directly to these positive forces. Moreover, a bubble is not indefinitely sustainable. Prices cannot go up forever, and 
when price increases end, then the increased demand that the price increases generated ends too. Then, a downward feedback can replace the upward feedback.

Nesse arcabouço, a elasticidade de oferta de crédito não é uma restrição à sua expansão. Se existirem oportunidades lucrativas, as instituições financeiras ampliam sua alavancagem introduzindo inovações financeiras, em geral, novos instrumentos de financiamento e captação de recursos. O condutor da política monetária grande parte das vezes valida a ação do sistema financeiro, injetando liquidez e socorrendo instituições em dificuldades, para evitar que dificuldades de determinadas instituições ou mercados se transformem em crises sistêmicas. Essa ação é fonte de risco moral e incentiva a tomada de posições mais arriscadas. A elasticidade juros da demanda de crédito também merece considerações. Em momentos de crise, as unidades insolventes não reduzem sua demanda, pelo contrário, a elevação dos serviços financeiros ampliará a necessidade de captação de recursos. A mesma qualificação vale para políticas restritivas que ao reduzirem a renda efetivamente auferida pelas unidades pode gerar uma crise de solvência generalizada ao invés de simples ajustes de posições financeiras.

\section{A Sustentabilidade do Processo}

As reversões mostram claramente a insustentabilidade do processo ancorado no gasto abastecido por endividamento e desequilíbrio das estruturas financeiras. Na primeira fase, fundamentalmente o desequilíbrio do setor privado e nas contas externas. Na segunda, os déficits fiscais substituíram os corporativos, eliminados após a crise de 2001. A relação entre esses desequilíbrios é expressa pela identidade:

$$
(Y d-G p)+(T-G g)+(M-X)=0
$$

em que Yd é a renda disponível, $G p$ e $G g$ correspondem ao gasto privado e do governo, respectivamente e $M$ são as importações e $X$ as exportações.

De acordo com Whalen (2006), a sustentabilidade do endividamento privado requer o atendimento a pelo menos uma dessas condições: crescimento da renda acima dos juros pagos, superávit primário adequado à manutenção de relações dívida/renda estáveis em níveis aceitáveis pelo mercado e aumento no valor dos ativos. As duas primeiras condições não foram observadas em nenhuma das fases de crescimento e a manutenção do endividamento passou a depender da apreciação dos ativos, as bolhas no mercado de ações 
e no mercado imobiliário. Dessa forma, apesar do crescente comprometimento da renda com o pagamento de serviços dos compromissos assumidos, as firmas e consumidores conseguiam contrair novos empréstimos. No entanto, vale ressaltar a vulnerabilidade da situação. O processo de endividamento é balizado pela valorização de ativos, muito voláteis e de retornos potenciais, enquanto os pagamentos dos serviços são definidos e extraídos da renda. Uma unidade dependente exclusivamente da apreciação dos ativos é claramente ponzi.

À exclusão dos primeiros trimestres de 1991, todo o período em análise foi marcado por déficits em conta corrente, pequenos até 1999. Tradicionalmente, o grande risco está relacionado à solvência e à demanda externa por dólares. A unificação monetária européia representou o surgimento de uma moeda forte, potencial concorrente do dólar. A depreciação continuada da moeda norte-americana incentiva a maior utilização do euro nas reservas internacionais dos países. Além disso, sendo a natureza do déficit relacionada ao consumo privado, sua insustentabilidade está inerentemente conectada ao arrefecimento do crescimento que reduzirá as importações. Outro fator de pressão é a compra de ativos norte-americanos por estrangeiros. Por outro lado, esse arrefecimento impactará as exportações norte-americanas à medida que esse movimento reflete nas demais economias. O efeito final é incerto. A partir de 2001, o déficit em conta corrente passou a ser acompanhado pelo crescente déficit fiscal, ressuscitando os déficits gêmeos da década de 80 . Segundo a visão convencional, o déficit limita o desenvolvimento de longo prazo por provocar o crowding-out do investimento - reduzindo os ganhos de produtividade - no curto prazo e por implicar a elevação da taxa de juros no longo prazo. A despeito dessa interpretação, que carece de maior comprovação empírica, a sua eliminação reduz o crescimento, a renda e, conseqüentemente, a lucratividade. Dessa forma o investimento privado tende a cair, mergulhando a economia em uma crise. Portanto, é preciso muito cuidado para não jogar a economia em recessão ao ajustar esses desequilíbrios. 


\section{A Fragilização e a Reversão}

Gráfico 2. Balanços dos Três Setores - Índice 100 (Situação de Equilíbrio) ${ }^{4}$

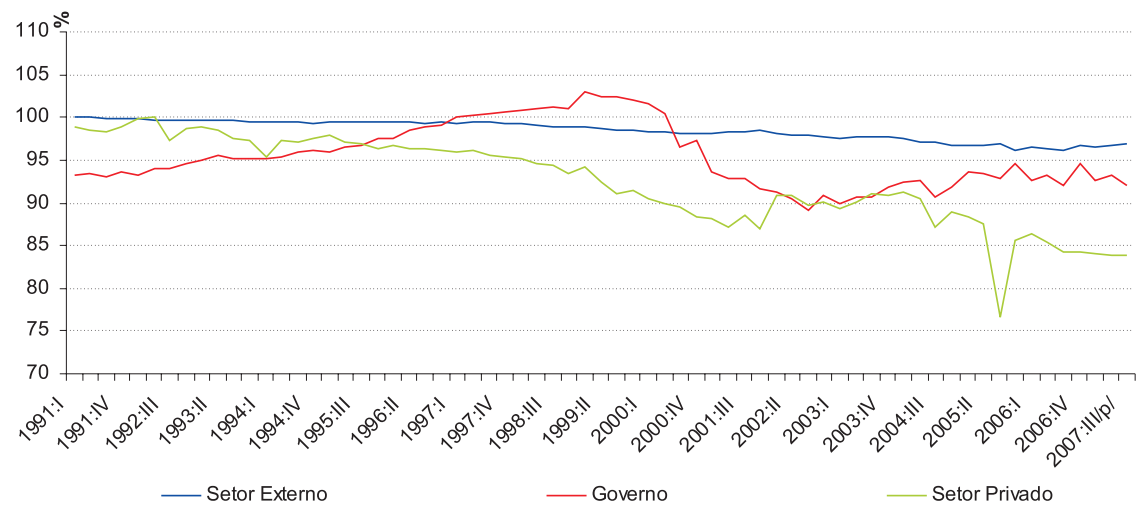

Fonte: NIPA e Flow of Funds.

Na primeira fase de crescimento, 1992 a 2000, as famílias e corporações ampliaram bastante o seu endividamento em relação à renda que atingiram níveis historicamente elevados. No final de 2000 , mais de $13 \%$ da renda das famílias estava comprometida com o pagamento de serviços de endividamento. Esse processo foi alimentado pela valorização dos ativos, notadamente ações.

As empresas se endividaram e ampliaram seus investimentos, comportamento corroborado pela valorização dos ativos em bolsas de valores. Esse fenômeno foi mais intenso nas empresas do setor de tecnologia e mídia. A valorização mostrava-se excessiva e descolada de fundamentos econômicos, caracterizando a formação de uma bolha. A visão oficial, por sua vez, descrevia um crescimento sustentável, assentado em grandes ganhos de produtividade.

As famílias detentoras dessas ações foram iludidas pelo aumento do valor de seus ativos e aumentaram seu endividamento. Os principais direcionamentos foram ampliações no consumo e compras de ações.

Os gastos das famílias e das corporações ao manter o crescimento econômico e geração de renda, validavam as posições financeiras assumidas. Em contrapartida, o governo promoveu ajustes graduais em sua estrutura financeira e passou a apresentar superávits fiscais a partir do terceiro trimestre de 1997. Esse movimento do governo,

4 Ao valor mais próximo do equilíbrio foi atribuído o índice 100. 
associado ao déficit em conta-corrente aos crescentes déficits na conta corrente, desaqueceu a demanda e a inflação permaneceu baixa. Assim, o FED não precisou aumentar os juros, medida com potencial nocivo tendo em vista o alto grau de comprometimento das rendas das famílias e corporações com pagamentos de juros.

Em fins dos anos 90, a economia apresentava sinais de superaquecimento e o FED aumentou os juros. Esse movimento e a elevação do preço do barril do petróleo foram suficientes para começar uma crise que se transformaria em recessão, após o estouro da bolha da Nasdaq. Os primeiros reflexos foram o acúmulo de estoques e o aumento da inadimplência, em queda desde 1991. Logo, a estrutura financeira privada foi ajustada e o déficit voltou aos níveis históricos. Entretanto, esse ajuste foi assimétrico e ficou concentrado nas corporações que cortaram investimentos e empregos. A economia entrou em recessão.

Em resposta, foi iniciado um processo de corte dos juros e os crescentes superáuits fiscais foram revertidos em déficits. A política fiscal, relegada a um segundo plano nos anos 90, voltou com força. As principais medidas foram o corte de impostos e o aumento dos gastos militares. A não extensão do Budget Enforcement Act, um conjunto de metas e medidas lançado no começo da década de 90 para melhorar a situação fiscal, foi emblemática.

$\mathrm{Na}$ segunda fase de crescimento iniciada em 2002, o crescimento foi puxado pelos gastos das famílias e do governo, sendo o setor imobiliário o líder da expansão.

Nessa etapa, as famílias ampliaram seu endividamento e o sistema financeiro alargou as margens de segurança. A queda de juros levou a um processo de refinanciamento que contou com o apoio oficial. Greenspan (2005) aponta a maior estabilidade e os juros baixos como facilitadores da tomada de decisões de longo prazo. Visto que boa parte do crescimento do consumo pessoal responde a ganhos derivados de ativos, ele analisa o processo através da taxa de endividamento sobre valor dos ativos, e, baseado em sua estabilidade, defende a normalidade do processo. Entretanto, o presidente do FED parecia ignorar a grande volatilidade dos ativos e a falta de suporte dos fundamentos para o comportamento dos preços residenciais. A descrição do processo dada por Shiller (2007) lembra em muito a formulação minskyana.

The increase since 1994 in home ownership appears to be due in large part to the remarkable housing boom. The boom psychology encouraged potential homeowners and encouraged lenders as well. Home buyers were encouraged by the potential investment returns. Mortgage lenders were encouraged since the boom reduces the default rate on lower-quality 
mortgages. The subprime mortgage market was virtually nonexistent before the mid 1990s, and rose to account for a fifth of all new mortgages by 2005 (SHILLER, 2007, p. 17).

Os valores das residências cresceram bem acima dos aluguéis e da inflação e forneciam condições para o refinanciamento de hipotecas. Parte desse valor foi direcionado ao consumo que, juntamente ao déficit fiscal, sustentou essa etapa de crescimento. A bolha dessa vez estava no mercado imobiliário

A conta-corrente manteve-se deficitária, vazando parte da demanda e permitindo a manutenção das baixas taxas de juros. No entanto, a manutenção de déficits gêmeos trouxe inúmeras preocupações quanto à sua sustentabilidade. Conforme a situação evoluía, a necessidade de um ajuste ficava mais clara. O déficit em contacorrente, em US $\$ 88$ bilhões no quarto trimestre de 2001, atingiu a marca de US $\$ 217$ bilhões no terceiro trimestre de 2006.

O investimento imobiliário cresceu entre 1991 e 2007 até atingir $5 \%$ em 2006. Entretanto, já em queda, no terceiro trimestre de 2006 ficou abaixo de 5\% do PNB e, pela primeira vez desde 1991, ficou abaixo de $4 \%$ no terceiro trimestre de 2007. Importante componente da demanda agregada, seu movimento é fundamental para explicar as flutuações econômicas na economia norte-americana. As 10 recessões enfrentadas pela economia norte-americana desde 1950 foram precedidas por quedas no investimento imobiliário.

A contração do crédito foi a principal conseqüência da reversão em curso. O FED baixou os juros e injetou liquidez nos mercados secundários em conjunto aos bancos centrais dos países desenvolvidos. $\mathrm{O}$ tesouro Norte-Americano apresentou plano que congela os juros das hipotecas do tipo subprime concedidas nos últimos anos por um período de 5 anos. A insuficiência do plano, formatado para reduzir assimetrias em um mercado, para resolver uma crise que se alastrou por toda economia ficou evidente e o governo lançou um novo, mais amplo, assentado no aumento da renda disponível para induzir aumento dos gastos privados. Ou seja, estimular a principal força motriz da economia norte-americana nas últimas décadas. O governo reitera o caráter transitório do plano, mas não propõe medidas de longo prazo. A aproximação das eleições presidências aumenta a urgência e limita as ações, especialmente aquelas que envolvam ajustes com perdas para determinados grupos. 


\section{$6 \bigcirc$ Papel de Cada Fator e os Determinantes do Endividamento das Familias}

Enquanto as análises acerca dos determinantes dos déficits do setor público e do setor externo da economia norte-americana são abundantes na literatura, poucos estudos se propõem a estudar o endividamento das familias, elemento fundamental para a compreensão das flutuações recentes dessa economia. Portanto, um desdobramento natural da análise desenvolvida, e talvez a sua principal contribuição, seja estudar o endividamento das famílias, sua dinâmica e seus determinantes. Mais especificamente, como o endividamento responde à variação nos preços dos ativos.

\subsection{Metodologia}

A análise de co-integração, proposta originalmente por Engle e Granger (1987), é o instrumento mais adequado para os propósitos do presente trabalho e, basicamente, refere-se a relações lineares estáveis entre as variáveis. Por seu turno, o modelo de correção de erro fornece as relações de curto prazo entre as variáveis. No contexto de mais de duas séries, a metodologia proposta por Johansen (1995) é mais adequada por permitir a existência de múltiplos vetores de co-integração. Além disso, essa metodologia é bastante utilizada em estudos macroeconômicos por tratar todas as variáveis como endógenas e eliminar problemas de simultaneidade, já que cada variável é explicada pelas próprias defasagens e pelas defasagens das demais.

Caso as variáveis sejam integradas de ordem 1, utiliza-se o Teorema da Representação de Granger, segundo o qual para um conjunto de variáveis I(1), o modelo de correção de erro e a relação de co-integração são representações equivalentes. Primeiro, estima-se um vetor autoregressivo - VAR que será a base para a construção do modelo de correção de erro com vetor de co-integração - VEC. A idéia do procedimento de Johansen consiste em verificar se um $\operatorname{VAR}(K)$ da forma:

$$
\begin{aligned}
& \Delta X_{t}=\Pi X_{t-1}+\sum_{i=1}^{K-1} \Gamma_{i} \Delta X_{t-i}+\varepsilon_{t} \\
& \Pi=\Pi_{1}+\ldots+\Pi_{k}-I \\
& \Gamma_{i}=-\sum_{j=i+1}^{K} \Pi_{j}
\end{aligned}
$$

174 Revista Análise Econômica, Porto Alegre, ano 26, n. 50, p. 161-184, setembro de 2008. 
pode ser escrito como um VEC(K-1). Quando isso acontece, de acordo com o Teorema da Representação de Granger, as variáveis são co-integradas.

$$
\operatorname{VEC}(\mathrm{K}-1): \Delta X_{t}=\alpha \beta^{\prime} X_{t-1}+\sum_{i=1}^{K-1} A_{i} \Delta X_{t-i}+\varepsilon_{t}
$$

Johansen propõe que seja realizado um teste para verificar se $\Pi=\alpha \beta$ ', baseando-se no posto da matriz Ï, utilizando o teste de razão de verossimilhança do traço (no mínimo $r$ vetores de co-integração).

Além da análise de co-integração propriamente dita, o VEC tem vários usos. Dentre eles, dois são úteis ao exame da economia norteamericana levado a cabo nesse estudo: causalidade de granger e decomposição da variância do erro de previsão. O primeiro relacionase a precedência temporal, a contribuição de determinada variável para a previsão de outra. A variável $z$ granger-causa a variável $y$ se o erro quadrático médio de previsão de $y_{t}$ baseado em um conjunto de informações que inclua os valores passados de $z_{t}$ for menor que outro baseado no mesmo conjunto de informação, porém excluindo os valores passados de $z_{t}$. Já a decomposição da variância do erro de previsão é útil por separar os determinantes do movimento de uma variável, o resultante de suas próprias variações da parcela que reflete movimentos de outras variáveis.

Alguns trabalhos anteriores aplicaram essa metodologia e encontraram resultados interessantes. Goodheart e Hofmann (2004) estudaram a relação de co-integração entre preços residenciais, mercado de ações e crédito em proporção do PIB em vários países. No que tange a relação entre o mercado de ações e o crédito em proporção do PIB, os resultados não indicaram a existência de relação entre elas para a maioria dos países. Andersson e Lauvsnes (2007) com base nas formulações teóricas de Keynes e Minsky, em especial a Hipótese da Fragilidade Financeira deste último, constroem um modelo VEC que se mostra melhor preditor que os outros testados para explicar o comportamento do índice de ações do mercado norueguês.

\subsection{O Modelo Desenvolvido}

A proposta é procurar as relações entre o endividamento das famílias, o índice Nasdaq e o preço das casas. Como todas as variáveis são heterocedásticas, aplicou-se o logarítimo natural a elas para reduzir suas variações. Portanto, as variáveis finais foram:

lnetborrowf: logarítimo natural do endividamento das famílias norte-americanas. Fonte: Flow of Funds. 
lnasdaq: logarítimo natural do Nasdaq composite Index. Fonte: Nasdaq.

lpcasa: logarítimo natural do índice SEPP/Case-Shiller de preços de casas norte-americanas. Fonte: StandartEPPoors.

As séries acima vão do primeiro trimestre de 1991 ao terceiro de 2007. Os testes de raiz unitária foram realizados e confirmaram sua presença nas séries. Os resultados encontram-se no apêndice.

Adotou-se o número de 7 defasagens do VAR proposto pelos critérios de Akaike e Erro Final de Previsão - FPE. Os testes de co-integração do traço e do máximo auto-valor indicaram 1 vetor de co-integração em todos os modelos à exceção do modelo com tendência quadrática, no qual o teste do traço acusou a existência de 2 vetores. A escolha do modelo seguiu análise gráfica e o critério de Pantula. O modelo indicado por este último foi descartado por ser indicado a situações nas quais as variáveis apresentam o mesmo padrão de comportamento, com diferenças de nível. O modelo estimado foi o seguinte:

$$
\Delta X_{t}=\alpha\left\langle\beta^{\prime} X_{t-1}+\mu_{1}\right\rangle+\mu_{2}+\sum_{i=1}^{6} P_{i} \Delta X_{t-i}+\varepsilon_{t}
$$

O teste LM, mais indicado para ordens mais baixas, rejeita a existência de autocorrelação dos resíduos nas 24 defasagens iniciais. Essa hipótese também pode ser descartada, a um nível de significância de $1 \%$, pelo teste de Portmanteau - mais potente conforme à medida em que aumenta a defasagem considerada - a partir da $33^{\text {a }}$ defasagem. $\mathrm{O}$ teste de Jarque-Bera ${ }^{5}$ rejeita a hipótese nula de normalidade dos resíduos. O problema está na curtose e decorre da existência de outliers nas séries. Apesar de ser uma qualidade desejada, a perda de normalidade não é impeditiva e compromete mais a realização dos testes tradicionais $\mathrm{t}$ e $\mathrm{F}$.

\subsection{Análise dos Resultados}

Tabela 2. Vetor de co-integração normalizado para a variável lnetborrowf ${ }_{t}$

\begin{tabular}{|c|c|c|c|}
\hline Inetborrowf $_{t}$ & lpcasa $_{t}$ & Inasdaq $_{t}$ & $\mu_{I}$ \\
\hline 1,00000 & $-1,59638$ & $-0,26752$ & $-3,75390$ \\
\hline & $(0,54070)$ & $(0,11896)$ & \\
\hline
\end{tabular}

Fonte: Elaboração Própria.

5 Os resultados dos testes de normalidade e autocorrelação estão à disposição para consulta, bastando solicitá-los ao autor.

176 Revista Análise Econômica, Porto Alegre, ano 26, n. 50, p. 161-184, setembro de 2008. 
O vetor de co-integração aponta o resultado esperado. Há uma relação estável entre os aumentos dos valores de ativos, nesse caso representados pelos preços das casa e pelo índice de ações da Nasdaq, e o aumento do endividamento das famílias. O modelo de correção de erro ajuda a explicar essa dinâmica. Os coeficientes de correção relativos às variáveis lpcasa e lnasdaq não são significativos. $\mathrm{O}$ ajuste a desequilíbrios de curto prazo é realizado por lnetborrowf. Os resultados estão na tabela abaixo:

Tabela 3. Coeficientes de velocidade de ajustamento

\begin{tabular}{|c|c|c|}
\hline Inetborrowft & lpcasat & lnasdaqt \\
\hline$-0,533173$ & 0,005354 & 0,137908 \\
\hline$(0,13651)$ & $(0,00703)$ & $(0,13546)$ \\
\hline
\end{tabular}

Fonte: Elaboração Própria.

A imposição de restrições sobre os valores desses coeficientes não promoveu alterações significativas nos resultados. Os resultados dos testes de Causalidade de Granger complementam a análise desenvolvida no parágrafo anterior. A variável lnetborrowf é grangercausada por cada variável individualmente e conjuntamente. Deste modo, o endividamento é precedido temporalmente pelo aumento do preço dos ativos. A variável lnetborrowf, por sua vez, não grangercausa nenhuma outra individualmente, apenas conjuntamente a lnasdaq granger-causa lpcasa. Já lnasdaq não é granger-causada por nenhuma outra, individualmente ou conjuntamente.

Tabela 4. Teste de Wald para Causalidade de Granger

\begin{tabular}{|c|c|c|c|}
\hline \multicolumn{4}{|c|}{$\boldsymbol{d}$ (Inetborrowf) } \\
\hline Excluída & $\chi^{2}$ & G.L. & Prob. \\
\hline$d$ (lpcasa) & 2.261 .245 & 6 & 0.0009 \\
\hline$d$ (lnasdaq) & 1.212 .574 & 6 & 0.0592 \\
\hline Todas & 3.129 .977 & 12 & 0.0018 \\
\hline
\end{tabular}

\begin{tabular}{|c|c|c|c|}
\hline \multicolumn{4}{|c|}{ d(lpcasa) } \\
\hline Excluída & $\chi^{2}$ & G.L. & Prob. \\
\hline$d$ (Inetborrowf) & 4.516 .799 & 6 & 0.6071 \\
\hline$d$ (lnasdaq) & 1.328 .461 & 6 & 0.0387 \\
\hline Todas & 2.123 .535 & 12 & 0.0470 \\
\hline
\end{tabular}

\begin{tabular}{|c|c|c|c|}
\hline \multicolumn{4}{|c|}{ d(Inasdaq) } \\
\hline Excluída & $\chi^{2}$ & G.L. & Prob. \\
\hline$d$ (Inetborrowf) & 2.763 .048 & 6 & 0.8379 \\
\hline d(lpcasa) & 3.034 .809 & 6 & 0.8045 \\
\hline Todas & 6.283 .855 & 12 & 0.9011 \\
\hline
\end{tabular}

Fonte: Elaboração Própria. 
A decomposição da variância do erro de previsão é importante por mostrar o quanto da variação de uma série pode ser explicado por uma determinada variável. O resultado é influenciado pela ordenação das variáveis escolhida para a realização da decomposição de Choleski. Testes realizados com especificações alternativas não apresentaram mudanças significativas em relação aos resultados apresentados abaixo, obtidos utilizado a ordenação: lnasdaq lpcasa lnetborrowf.

Tabela 5. Decomposição da Variância do Erro de Previsão

\begin{tabular}{|c|c|c|c|c|}
\hline \multicolumn{5}{|c|}{ Decomposição da Variância de lnetborrowf: } \\
\hline Periodo & D. Padrão & lnetborrowf & lpcasa & lnasdaq \\
\hline \multicolumn{5}{|c|}{} \\
\hline 1 & 0,1167 & 99,9909 & 0,0027 & 0,0064 \\
\hline 2 & 0,1263 & 86,1121 & 0,0277 & 1,386 \\
\hline 3 & 0,144 & 67,5701 & 18,651 & 1,3779 \\
\hline 4 & 0,1813 & 61,261 & 29,9356 & 8,8034 \\
\hline 5 & 0,2158 & 46,3357 & 42,6228 & 11,0416 \\
\hline 6 & 0,2678 & 31,997 & 58,1048 & 9,8982 \\
\hline 7 & 0,3207 & 26,8438 & 65,99 & 7,1662 \\
\hline 8 & 0,37 & 21,5555 & 70,4252 & 8,0193 \\
\hline 9 & 0,4269 & 18,8831 & 74,0598 & 7,0571 \\
\hline 10 & 0,4726 & 18,3858 & 75,1625 & 6,4517 \\
\hline
\end{tabular}

\begin{tabular}{|c|c|c|c|c|}
\hline \multicolumn{5}{|c|}{ Decomposição da Variância de lpcasa } \\
\hline Periodo & D. Padrão & lnetborrowf & lpcasa & lnasdaq \\
\hline \multicolumn{5}{|c|}{} \\
\hline 1 & 0,0057 & 0 & 96,1956 & 3,8044 \\
\hline 2 & 0,0128 & 0,2116 & 98,981 & 0,8074 \\
\hline 3 & 0,0202 & 0,3773 & 99,2878 & 0,3349 \\
\hline 4 & 0,0279 & 0,7373 & 99,0324 & 0,2304 \\
\hline 5 & 0,0382 & 1,3663 & 98,4851 & 0,1486 \\
6 & 0,0498 & 2,285 & 97,6128 & 0,1022 \\
\hline 7 & 0,0611 & 3,5947 & 96,28 & 0,1253 \\
8 & 0,0717 & 5,0795 & 94,7335 & 0,1869 \\
\hline 9 & 0,0832 & 6,4807 & 93,131 & 0,3884 \\
10 & 0,0954 & 7,9358 & 91,3372 & 0,727 \\
\hline \multicolumn{5}{|c}{}
\end{tabular}

178 Revista Análise Econômica, Porto Alegre, ano 26, n. 50, p. 161-184, setembro de 2008. 


\begin{tabular}{|c|c|c|c|c|}
\hline \multicolumn{5}{|c|}{ Decomposição da Variância de lnasdaq } \\
\hline Periodo & D. Padrão & lnetborrowf & lpcasa & lnasdaq \\
\hline \multicolumn{5}{|c|}{} \\
\hline 1 & 0,1137 & 0 & 0 & 100 \\
\hline 2 & 0,1773 & 0,0104 & 0,5956 & 99,394 \\
\hline 3 & 0,2439 & 0,0745 & 0,345 & 99,5806 \\
\hline 4 & 0,3098 & 0,1215 & 0,2301 & 99,6484 \\
\hline 5 & 0,3558 & 0,3079 & 0,1842 & 99,5079 \\
6 & 0,3922 & 0,3482 & 0,2104 & 99,4414 \\
\hline 7 & 0,4269 & 0,3838 & 0,3957 & 99,2205 \\
8 & 0,455 & 0,5304 & 0,6488 & 98,8208 \\
9 & 0,4795 & 0,6094 & 0,8569 & 98,5337 \\
\hline 10 & 0,5027 & 0,6815 & 0,9592 & 98,3593 \\
\hline
\end{tabular}

Fonte: Elaboração Própria.

A decomposição da variância mostra que lpcasa tem um elevado poder preditivo sobre o comportamento de lborrowf já que após 10 períodos consegue explicar mais de $75 \%$ de sua variação. A variável lnasdaq explica menos de $7 \%$ dessa variação. Essa variável tem um poder preditivo quase insignificante em relação ao comportamento de lpcasa. Por sua vez, as outras variáveis têm pouco poder preditivo sobre ela. A variável lborrowf tem razoável poder explicativo acerca do comportamento de lpcasa explicando mais de $7 \%$ de sua variação após 10 períodos.

\section{Consideraçõs Finais}

O período recente ilustra bem os benefícios e perigos associados ao funcionamento do sistema financeiro. Por um lado, ele é responsável pelo financiamento do consumo e do investimento, componentes da demanda agregada e elementos fundamentais para assegurar o crescimento da economia. Por outro, as crises financeiras, naturalmente decorrentes de seu funcionamento, terminam invariavelmente em recessão econômica. Essas crises estão relacionadas ao uso especulativo do crédito, alimentando a formação de bolhas, por exemplo. O principal problema nesse caso é a insustentabilidade desse processo. A reversão tem efeitos drásticos e pode anular os benefícios econômicos obtidos anteriormente. A maior recorrência dessas crises recentemente é resultado do processo global de desregulamentação dos mercados iniciado nos anos 80. Esse processo e o avanço das telecomunicações são, em grande medida, responsáveis pela 
volatilidade observada nos mercados financeiros nas últimas décadas. $\mathrm{O}$ desenvolvimento de novos mercados e instrumentos financeiros reduziu o poder de intervenção dos gestores de política monetária. No caso norte-americano, que conta com um sistema financeiro desenvolvido, seus impactos sobre os demais setores econômicos são maiores.

Esses eventos, as inovações financeiras e a melhor gestão dos passivos possibilitaram a expansão e acentuação dos desequilíbrios das estruturas financeiras que atingiram níveis historicamente elevados. Os mercados secundários mais profundos e a maior liberdade global do capital ampliaram a oferta de crédito e possibilitaram a tomada de posições cada vez mais arriscadas. Boa parte das aplicações na Nasdaq e das compras de CDOs foi realizada por estrangeiros. As novas práticas de avaliação financeira aparentemente trouxeram maior segurança às decisões, fundamentadas em preceitos estritamente racionais e técnicos. As agências de rating tiveram participação ativa nas duas bolhas ao fundamentarem a valoração das ações e a expansão do crédito. Acreditava-se ainda nos efeitos estabilizadores desses capitais que poderiam resolver problemas locais de liquidez. E assim, tanto os credores quanto os tomadores de empréstimo ampliaram sua exposição ao risco.

As unidades econômicas ingressaram em um ciclo minskyano típico. As unidades se endividam, ampliam os gastos e a apreciação dos ativos resultante corrobora essa atitude. A alavancagem é ampliada e as unidades ampliam sua vulnerabilidade a eventos que revertam o ciclo econômico. Dada a incerteza que permeia o ambiente econômico, eventos de impacto real reduzido podem provocar reversões das expectativas, desencadeando uma grave crise econômica. Nesse caso, o principal problema é a disponibilidade de crédito. Na sua ausência, as unidades econômicas enfrentarão problemas para cumprir suas obrigações financeiras e o receio da repetição da crise de 1929 gera os incentivos à atuação dos formuladores de política econômica. Essa atuação, como em 2001 e 2007, é reativa e não envolve medidas de longo prazo que promovam ajustes estruturais. Dessa forma, os desequilíbrios não são corrigidos e o risco moral incentiva a manutenção de ações que engendraram a crise.

Em termos gerais, os resultados empíricos apontam uma relação mais forte do endividamento com o preço das residências que com a variação da Nasdaq. Esse resultado, em certa medida, reflete o direcionamento da aplicação de recursos em direção ao setor imobiliário e uma maior aversão das famílias ao investimento no mercado de ações, especialmente em empresas menos tradicionais. A grande 
integração dos mercados financeiros e sua maior volatilidade deixam o índice da Nasdaq sujeito a variações geradas por fatores que afetem pouco as condições internas.

Atualmente, os analistas conferem grande ênfase à estabilidade macroeconômica, mais especificamente da taxa inflação e das condições jurídico-institucionais. Contudo, boa parte ignora um dos elementos mais fundamentais: o preço dos ativos. Ele afeta as decisões de consumo e investimento, e seus movimentos explicam grande parte das flutuações econômicas. A instabilidade recente atinge parcela expressiva da população que não tem estoque de riqueza e diversificação de aplicações suficientes para enfrentar as "fases de ajustamento", cada vez mais recorrentes. O padrão recente de intervenção, injeções de liquidez nos mercados secundários, procura evitar crises de solvência e acaba beneficiando os credores em detrimento a medidas que poderiam aquecer a demanda e reduzir o desemprego. A gravidade da crise imobiliária, não mais restrita ao setor, levou o governo a lançar um ousado programa de desoneração, de caráter mais amplo. A discussão de propostas e a indicação de soluções para redução dessa instabilidade vão além do escopo desse trabalho. Porém, se não aponta saídas, a análise da situação recente norteamericana é essencial para mostrar sua necessidade e urgência.

\section{Referências Bibliográficas}

ARESTIS, P. The Post-Keynesian Approach to economics: an alternative analysis of economic theory and policy. Edward Elgar, 1992. 336p.

DICKEY, D. A., FULLER, W. A. Likelihood ratio statistics for autoregressive time series with a unit root. Econometrica, v. 49, p. 1057-1073, 1981.

DYMSKI, G. E POLLIN, R. Hyman Minsky as hedgehog: the power of the Wall Street paradigm, em Fazzari, S. E Papadimitriou, D. (eds) Financial Conditions and Macroeconomic Performance, New York: M. E. Sharpe. 1992.

ENGLE, R. F., GRANGER C. W. J. Cointegration and error correction: representation, estimation and testing. Econometrica, v. 55, n. 2, p. 251-276, 1987.

GOODHEART, C., HOFMANN, B. Deflation, credit and asset prices. In: BURDEKIN, R.; SIKLOS, P. (eds) Deflation. Current and historical perspectives. Cambridge University Press, 2004.

GREENSPAN, A. The Federal Reserve's report on monetary policy. Testemunho ao comitê de bancos, habitação e questões urbanas do Senado dos EUA. 2000. Disponível em: $<$ http://www.federalreserve.gov/boarddocs/hh/> . Acesso em: 22/01/2008.

. Mortgage banking. Discurso Proferido pelo Chairman do FED durante a Convenção de banqueiros norte-americanos. 2005. Disponível em: <http:// www.federalreserve.gov/boardDocs/Speeches/2005/200509262/default.htm > . Acesso em: 20/01/2008. 
$616 \mathrm{p}$.

. A Era da Turbulência: Aventuras em um Novo Mundo. Editora Campus. 2007,

JOHANSEN, S. Likelihood based inference in cointegrated vector auto-regressive models. Oxford University Press, Oxford, 1995. 280p.

KREGEL, J. The Natural Instability of Financial Markets. Working Paper, v. 523. The Levy Economics Institue. 2007.

KWIATKOWSKI et al. Testing the null hypothesis of stationarity against the alternative of unit root. Journal of Econometrics, v. 54, p. 159-178, 1992.

MADDALA, G. S., KIM, I. M. Unit roots, cointegration, and the structural change. Cambridge University Press. 1998.

MEHRLING, P. The Vision of Hyman P. Minsky. Journal of Economic Behavior and Organization, v. 39, p. 129-158. 1999.

MINSKY, H. Can "it" happen again? Essays on instability and finance. New York: M. E. Sharpe, 1982. 301p.

PÁSTOR, L'.; VERONESI, P. Was there a Nasdaq bubble in the late 1990s? Journal of Financial Economics, v. 81, p. 61-100, 2006.

PARENTEAU, R. U.S Household Déficit Spending. Public Policy Brief, n. 88. The Levy Economics Institue, 2006.

PHILLIPS, P. C. B.; PERRON, P. Testing for unit root in time series regression. Biometrika, V. 75, p. 335-346, 1998.

SHILLER, R. J. Bubbles, Human Judgment, and Expert Opinion. Cowles Foundation Discussion Paper, n. 1303. Yale University. 2001.

SHILLER, R. J. Understanding Recent rends in House Prices and Home Ownership. Cowles Foundation Discussion Papers. Yale University. 2007.

WHALEN, C. The U.S Credit Crunch of 2007: A Minsky Moment. Public Policy Brief, n. 92. The Levy Economics Institue, 2007.

WRAY, L. Lessons fron the Subprime Meltdown. Working Paper, n. 522. The Levy Economics Institue. 2007.

182 Revista Análise Econômica, Porto Alegre, ano 26, n. 50, p. 161-184, setembro de 2008. 


\section{Anexos}

Tabela 6. Testes de Raiz Unitária para lnetborrowf

\begin{tabular}{|c|c|c|c|c|c|}
\hline \multicolumn{5}{|c|}{ ADF } \\
\hline Modelo & Defasagens & Estatística & p-valor & \\
\hline Constante e Tendência & 2 & -3.456 .459 & 0,053 & \\
\hline \multicolumn{7}{|c|}{ KPSS } \\
\hline Phillips-Perron & & Modelo & Estatística & Valor Crítico $^{*}$ \\
\hline Modelo & Estatística & p-valor & Com constante & 1,010635 & 0,463 \\
\hline Sem termos deterministas & 1.728 .323 & 0,9788 & & 0,125177 & 0,146 \\
\hline Com constante & $-0,708515$ & 0,837 & Constante e Tendência & 0 \\
\hline Constante e Tendência & $-6,21724$ & 0 & & & \\
\hline
\end{tabular}

Fonte: Elaboração Própria.

Notas: * indica um nível de significância de 5\%

Tabela 7. Testes de Raiz Unitária para lpcasa

\begin{tabular}{|c|c|c|c|c|c|}
\hline \multicolumn{5}{|c|}{ ADF } \\
\hline Modelo & Defasagens & Estatística & p-valor & \\
\cline { 1 - 4 } Sem termos deterministas & 5 & 0,969896 & 0,9103 & \\
\hline \multicolumn{7}{|c|}{ Phillips-Perron } & \multicolumn{2}{c|}{ KPSS } \\
\hline Modelo & Estatística & p-valor & Modelo & Estatística & Valor Crítico* \\
\hline Sem termos deterministas & 4,559661 & 1 & Com constante & 0,974602 & 0,463 \\
\hline Com constante & 4,465084 & 1 & Constante e Tendência & 0,27175 & 0,146 \\
\hline Constante e Tendência & $-1,556095$ & 0,7995 & & & \\
\hline
\end{tabular}

Fonte: Elaboração Própria.

Notas: * indica um nível de significância de 5\%

Tabela 8. Testes de Raiz Unitária para Inasdaq

\begin{tabular}{|c|c|c|c|c|c|}
\hline \multicolumn{6}{|c|}{$\mathrm{ADF}$} \\
\hline Modelo & Defasagens & Estatística & $\mathrm{p}$-valor & & \\
\hline Sem termos deterministas & 0 & 1,668624 & 0,9759 & & \\
\hline \multicolumn{3}{|c|}{ Phillips-Perron } & \multicolumn{3}{|c|}{ KPSS } \\
\hline Modelo & Estatística & p-valor & Modelo & Estatística & Valor Crítico* \\
\hline Sem termos deterministas & 1,283905 & 0,9482 & Com constante & 0,830402 & 0,463 \\
\hline Com constante & $-1,596578$ & 0,4787 & Constante e Tendência & 0.196863 & 0,146 \\
\hline Constante e Tendência & $-1,494013$ & 0,8219 & & & \\
\hline
\end{tabular}

Fonte: Elaboração Própria.

Notas: * indica um nível de significância de 5\%

Tabela 9. Testes de Co-integração

\begin{tabular}{|c|c|c|c|c|c|}
\hline $\begin{array}{c}\text { Tendência dos } \\
\text { dados }\end{array}$ & Nenhuma & Nenhuma & Linear & Linear & Quadrática \\
\hline & $\begin{array}{c}\text { Sem } \\
\text { intercepto }\end{array}$ & Intercepto & Intercepto & Intercepto & Intercepto \\
\cline { 2 - 6 } & $\begin{array}{c}\text { Sem } \\
\text { tendência }\end{array}$ & $\begin{array}{c}\text { Sem } \\
\text { tendência }\end{array}$ & $\begin{array}{c}\text { Sem } \\
\text { tendência }\end{array}$ & Tendência & Tendência \\
\hline Traço & 1 & 1 & 1 & 1 & 2 \\
\hline Max. Auto-Valor & 1 & 1 & 1 & 1 & 1 \\
\hline
\end{tabular}

Fonte: Elaboração Própria.

Notas: A um nível de significância de 5\% utilizando valores críticos de MacKinnonHaug-Michelis (1999). 


\section{Gráfico 3. O Mercado de Ações}

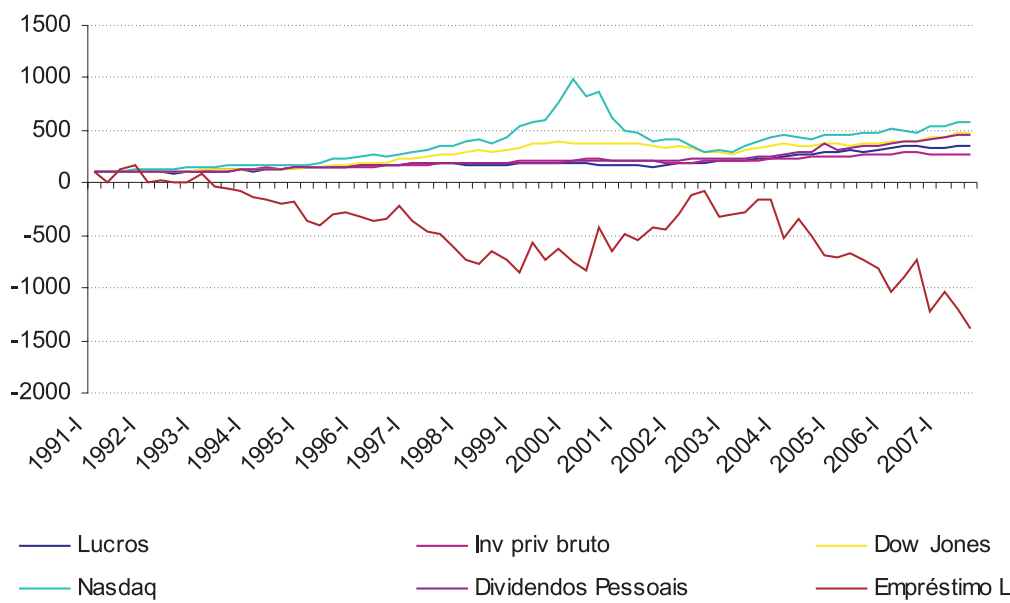

Fontes: NIPA, Flow of Funds, Nasdaq e Dow Jones.

\section{Gráfico 4. O Mercado Imobiliário}

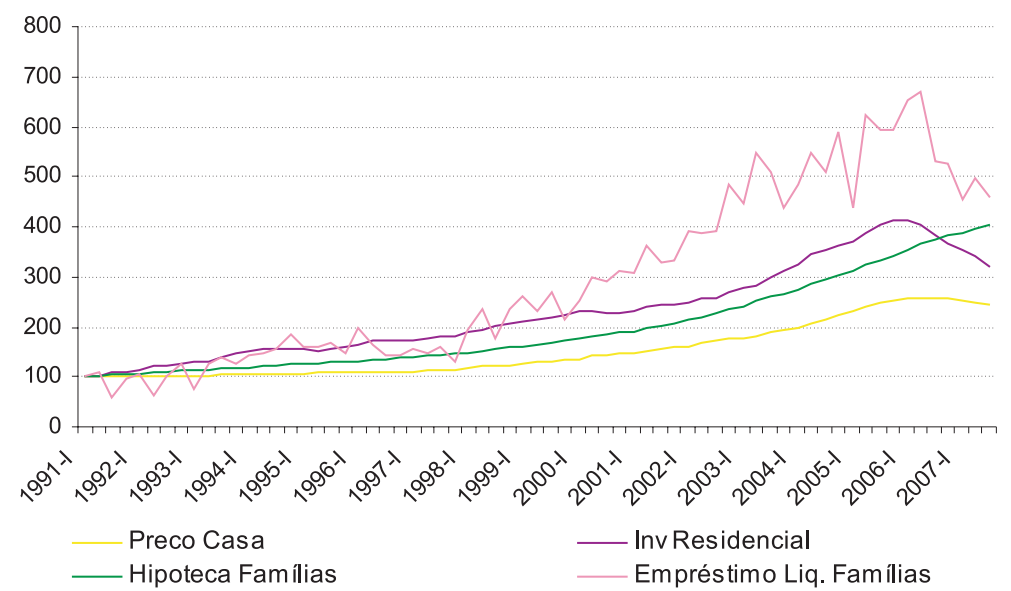

Fontes: NIPA, Flow of Funds.

184 Revista Análise Econômica, Porto Alegre, ano 26, n. 50, p. 161-184, setembro de 2008. 


\section{As práticas de conluio nas licitações públicas à luz da teoria dos jogos}

Francisco Campos*

Resumo: O presente artigo avalia se as regras inseridas nos procedimentos licitatórios são eficazes no combate às práticas de conluios e se geram incentivos para os licitantes apresentarem propostas verdadeiras (aquelas que não extraem todo excedente econômico). Em vista disso, utiliza-se a teoria dos jogos e a teoria econômica dos cartéis como instrumentos de análise. As principais conclusões do artigo são que os incentivos econômicos vislumbrados pelos agentes e a limitada eficácia dos instrumentos licitatórios relativos aos procedimentos de divulgação, julgamento e desclassificação das propostas não evitam as práticas de conluio nas aquisições do setor público, exceto no pregão eletrônico com muitos participantes, onde a probabilidade de êxito das práticas de conluio são reduzidas.

Palavras-chave: Licitações Públicas, Conluios, Teoria dos Jogos.

Abstract: The present article analyzes as the cartels act in the public administration and if the inserted rules in the biddings are efficient in the combat to the practical ones of collusions and generate incentives them bidders to present true proposals (those that they do not extract all exceeding economic). In sight of this, it is used games theory and the economic theory of the cartels as analysis instruments. The main conclusions of the article are that the economic incentives glimpsed by the agents and the limited effectiveness of the relative instruments of bidding to the spreading procedures, judgment and declassification of the proposals do not prevent the practical ones of collusion in the acquisitions of the public sector, except in the electronic biddings with many participants, where the probability of success of the practical ones of collusion is reduced.

Keywords: Bidding, Collusions, Game Theory.

JEL Classification: D43; D44; D82; H57.

\section{Introdução}

Assim como nos gastos privados, a eficiência do gasto público pressupõe que numa aquisição de bens/serviços se esteja pagando o valor efetivo da mercadoria, ou seja, aquele preço que se iguala

* Mestre em Economia pelo CAEN/UFC. E-mail: camposfao@gmail.com 
aos custos marginais. Mas, essa situação trata-se de uma economia de concorrência perfeita, que de fato é pouco praticada (restrita a alguns mercados). Fora dessa lógica de mercado de concorrência perfeita, a eficiência do gasto público, considerando que a compra/ aquisição seja oportuna e necessária, consiste na ausência de qualquer tipo de desperdício na sua aquisição ou contratação ou ainda no seu menor custo possível de financiamento, no caso de existência de déficit público.

Contudo, uma situação comum na administração pública é a formação de cartel/conluio para a prática de sobrepreço nas licitações públicas, principalmente quando se refere a um mercado com poucos fornecedores, onde há maiores facilidades de se coordenar um acordo. Além dessa imperfeição de mercado, os procedimentos normativos das aquisições (Lei no 8.666/93 e 10.520/02) e a legislação específica antitrustes (comandada pela Lei $n^{\circ} 8.884 / 94$ ) não se mostram suficientemente adequados para evitar as atuações dos cartéis/conluio, exceto no caso de pregão eletrônico com muitas empresas participantes, como se verá adiante. Tanto que, recentemente, o Governo Federal encaminhou ao Congresso Nacional o Projeto de Lei $n^{\circ}$ 7709/2007 no sentido de reformar a Lei $n^{\circ} 8.666 / 93$ e ampliar o uso do pregão, visto que a cada ano o volume de recursos decorrentes da ineficiência dos gastos atrelada a alguma prática de conluio se torna exorbitante. Pelas estimativas da Secretaria de Defesa Econômica, do Ministério da Justiça, para compras e aquisições anuais da ordem de $R \$ 300$ bilhões, o prejuízo gira entre $R \$ 25$ a $R \$ 40$ bilhões (site www.mj.gov.br - comunicado de 30/05/2007).

As evidências das práticas de cartéis nas compras públicas podem ser vista na mídia, as quais constantemente são noticiadas em relatos de alguma operação policial, tais como as operações da Polícia Federal: Operação Guabiru (17/05/04), Operação Vampiro (19/05/04), Operação Sentinela (02/12/04), Operação Sanguessuga (04/05/2006), Operação Carta Marcada (02/05/2006), Operação Fox (18/07/2006) entre outras.

São freqüentes, ainda, as notícias que os gerentes das áreas de prestação de serviços das empresas se reúnem, e os grandes dividem o mercado. Às vezes, os pequenos ganham. Como é uma informação de conhecimento comum entre as empresas, o grande interesse dos pequenos é receber comissão para não participar, ou receber comissão para dar cobertura aos grandes.

Por isso, o objetivo do presente artigo consiste em analisar como os cartéis atuam na administração pública e se as regras constantes dos procedimentos licitatórios são eficazes no combate às práticas de 
conluios e nos incentivos dos licitantes a apresentarem propostas verdadeiras (aquelas que não extraem excedente econômico). Utilizase a teoria dos jogos e a teoria econômica dos cartéis (a microeconomia da concorrência imperfeita) como instrumentos de análise, visto que essas teorias captam as interações e os incentivos econômicos inerentes ao processo decisório de provimento de bens e formação de preços.

Outro interesse do estudo que se segue é a possibilidade de ampliar o campo de análise do setor público por meio da teoria dos jogos. O setor público convive com diversos problemas de incentivos e de assimetria de informações nos quais geram atividades econômicas ilícitas e ineficientes, cujas soluções impactam a vida dos indivíduos por meio de carga tributária elevada e distorciva, déficit público, morosidade judiciária, realocações indevidas de gastos entre outras conseqüências diretas.

Do ponto de vista teórico, faz-se uma breve contextualização dos aspectos da teoria dos jogos que serão considerados na análise das práticas de conluio nas licitações públicas, bem como caracteriza-se a atuação dos cartéis/conluios. Sob a ótica institucional, abordada-se as principais regras inseridas nos procedimentos utilizados pela administração pública na aquisição de bens se serviços, na forma da Lei de Licitações $n^{\circ} 8.666 / 93$ e $n^{\circ} 10.520 / 02$. Posteriormente, segue a análise propriamente dita, na forma de respostas às indagações que serão levantadas em termo de título sobre o objeto em foco, tais como: há incentivo para uma empresa apresentar uma proposta verdadeira? $\mathrm{Na}$ medida do possível, essa técnica será usada no presente trabalho.

\section{Considerações Teóricas e Institucionais}

\section{a) Teoria do Jogos}

Jogo é toda a situação em que existem duas ou mais entidades em uma posição em que as ações de uma interferem nos resultados de outra. Já a teoria dos jogos consiste em um instrumental matemático para modelar as interações de dois ou mais agentes numa tomada de decisão. A teoria dos jogos estuda o processo de decisão estratégica onde as ações das outras pessoas revelam algo sobre o que um agente (ou vários agentes) sabe, com isso, há o uso desta informação para orientar as próprias ações desses agentes. Isto é, há uma interdependência estratégica, principalmente quando se trata de jogos não cooperativos. Mesmo nesse tipo de jogo, o bem estar individual não depende só das suas ações, mas, também das ações de outros indivíduos. De fato, as inter-relações permitem uma combinação de informações 
extraídas com as que o agente tem acerca da questão e o uso desse conjunto de informações para definir dispositivos estratégicos numa tomada de decisão.

A teoria dos jogos é usada para se estudar assuntos tais como leilões, negociações empresariais e comerciais, evolução genética, comportamentos políticos, práticas de análise econômica de concorrência e determinação de preços, política de comércio internacional, externalidades entre outros assuntos relevantes.

Os jogos na forma normal consistem na apresentação de um conjunto de jogadores, um conjunto de estratégias para cada jogador e um conjunto de resultado (payoffs) do jogo, que descreve a utilidade de cada jogador quando um dado conjunto de estratégias é escolhido. É apresentado por meio de matrizes, onde constam os elementos retromencionados.

Há duas hipóteses básicas nesses jogos, que são a racionalidade dos jogadores (preferem mais a menos e maximizam sua utilidade) e o conhecimento comum (commom knowledge). Nesta última, cada jogador conhece os resultados e as estratégias de todos os jogadores. Assim, todos os jogadores conhecem a estrutura do jogo, conhecem que seus rivais sabem disso, conhecem que seus rivais sabem que eles sabem disso.

A solução do jogo de estratégias puras ${ }^{1}$ ocorre por meio da verificação da dominância das estratégias ou via Equilíbrio de Nash. No primeiro caso, procura-se uma estratégia dominante (pode se chegar a ela por meio da eliminação iterada das estratégias dominadas), aquela que é melhor para o jogador independentemente da escolha do outro jogador, assim, o jogador racional sempre jogará a estratégia dominante. No Equilíbrio de Nash, ${ }^{2}$ que trata da estratégia que garante o melhor resultado independentemente das escolhas dos outros jogadores, não há incentivo a desvios caso as escolhas dos outros jogadores sejam mantidas.

Agora, ilustra-se os conceitos abordados acima por meio de um jogo simultâneo ${ }^{3}$ bastante conhecido na literatura da teoria dos jogos,

1 Existem os jogos de estratégias mistas que são aqueles onde se atribui probabilidades às jogadas para encontrar o equilíbrio estável. Nas estratégias puras, as escolhas são determinísticas e nas estratégias mistas as escolhas são randomizadas.

2 Principalmente por meio de estratégias mistas, pois caso um jogo não tenha um ou tenha mais que Equilíbrio de Nash em estratégias puras, o equilíbrio encontrado em estratégia mista será estável.

3 Nos jogos simultâneos cada jogador ignora as decisões dos demais no momento em que toma a sua própria decisão (os jogadores se movem somente uma vez e ao mesmo tempo), em contrapartida, os jogos seqüenciais o jogador imagina as respostas futuras dos outros jogadores e usa-as para calcular qual é o seu melhor lance. 
que trata da solução de um conflito chamado de "Dilema dos Prisioneiros", no caso não repetido. Nesse jogo dois prisioneiros são instados a confessar um crime por meio de um sistema de incentivo, embora o melhor resultado fosse ambos não confessarem. Eis o sistema de incentivo implementado: i) o prisioneiro pode escolher entre confessar e não confessar. ii) se apenas um confessa ele é solto e o outro é condenado a seis meses de prisão. Se ambos negarem, cada um pega um mês de prisão. Se ambos confessarem a pena é de três meses para cada um.

Dilema dos Prisioneiros

\begin{tabular}{|l|l|l|l|}
\cline { 3 - 4 } \multicolumn{2}{c|}{} & \multicolumn{2}{c|}{ Prisioneiro 2 } \\
\cline { 3 - 4 } \multicolumn{2}{c|}{ Confessa } & Não Confessa \\
\hline \multirow{2}{*}{ Prisioneiro 1 1} & Confessa & $-3 ;-3$ & $0 ;-6$ \\
\cline { 2 - 4 } & Não Confessa & $-6 ; 0$ & $-1 ;-1$ \\
\hline
\end{tabular}

Os payoffs são negativos porque se trata de tempo na prisão, ou seja, uma desutilidade para um agente racional. No caso acima, há uma estratégia dominante para cada jogador, pois é sempre melhor confessar, não importando o que o outro jogador escolha. Diante disso, a solução do jogo é (confessa, confessa). Vale ressaltar que esse resultado decorre do fato dos dois prisioneiros não poderem se comunicar, pois eles foram colocados em celas separadas. Caso houvesse comunicação entre eles, os resultados dependeriam da possibilidade de estabelecimento de compromissos que pudessem ser garantidos por meio de ameaças críveis para evitar trapaças. Uma ameaça crível é aquela possível de ser realizada, mesmo que o agente ameaçador incorra em prejuízos no estágio seguinte. Por exemplo, cobrar preços abaixo dos custos e fazer o jogador que não honrou o acordo perder mercado.

Um ramo da teoria dos jogos é o desenho mecanismo, usado quando há problemas de informação privada (incompleta) nos modelos de principal-agente, como forma de prover incentivos para que a parte mais informada não se desvie dos objetivos avençados (direção desejada). Os modelos de principal-agente tratam de situação onde existe informação ou ação cuja utilização por parte do agente pode gerar vantagens numa relação de contrato/negócio. Quando se refere a uma ação diz-se que é problema de moral hazard (por exemplo no contrato de seguro, não se sabe ao certo do comportamento do segurado, que pode agir de forma a facilitar a ocorrência do sinistro), 
quando for uma informação escondida, tem-se um problema de seleção adversa (por exemplo há dois tipos de agentes e a dificuldade de distingui-los leva a uma seleção adversa, no qual pode gerar disfunções econômicas. Uma ilustração clássica refere-se ao mercado de carros usados: usado de boa qualidade e usado de má qualidade. As sinalizações (emissão de um sinal por parte do agente ou pelo principal) são remédios contra esses problemas. ${ }^{4}$

Vale ressaltar que, em vista do presente trabalho se referir a licitações, nosso interesse será no caso no qual o principal toma a iniciativa de propor regras de forma a reduzir o rendimento da informação do agente ou fazer com que ele revele seu tipo.

Uma das aplicações dos modelos de desenho de mecanismo são os leilões, que podem ser conceituados como um mecanismo de mercado para equilibrar a oferta e a demanda. Os leilões são do tipo selado (envelope fechado) e os abertos (lances públicos); e os mais conhecidos são os de primeiro preço, onde o lance maior ganha e paga o valor desse lance, e o de segundo preço, o lance mais alto ganha mais paga o valor do segundo lance mais alto.

Pode-se inferir que uma licitação pública para aquisição de um bem segue a lógica de um leilão selado de primeiro preço, mas o vencedor é aquele que apresenta o valor mais baixo. Além disso, a licitação é um mecanismo que permite que os licitantes apresentem suas propostas e a administração escolha aquela que for mais vantajosa.

Visto da ótica do setor público, as aquisições de bens por esse setor consistem em um jogo no qual reflete uma situação com apenas um vencedor para cada jogo, isto é, não há um equilíbrio na forma em que todos os jogadores permanecem fornecendo produto para aquele demandante do setor público, embora com quantidades e resultados diferentes. Ademais, não é um jogo de soma zero, pois o lucro do vencedor não é necessariamente do tamanho da perda do vencido.

b) Cartel e Conluio

O cartel consiste de um grupo de ofertadores que fizeram um acordo explícito para limitar competição entre eles em seu próprio benefício. O objetivo é atuar como se fosse um monopólio, mas enquanto no monopólio a decisão cabe apenas a um produtor, o cartel consiste de uma associação voluntária de tomadores de decisão, cada qual consciente que o seu lucro depende do comportamento

4 Exemplos de sinalização: i)garantia adicional dada pelas fábricas para sinalizar que o seu produto tem qualidade e diferenciar daqueles de menor qualidade; ii)distribuição de dividendos no sentido de mostrar que a empresa se enquadra no bom cenário; iii) no mercado de trabalho, usar o nível educacional para sinalizar maior produtividade. 
do todos os ofertadores da indústria. Portanto envolve muito mais que uma simples definição do nível de preço e quantidade maximizante do lucro.

Os acordos surgem quando as firmas percebem a inconsistência do processo concorrencial em que estão inseridas e o fato que a interação entre elas de forma cooperativa pode levar à obtenção de uma ótima de lucratividade. A Interdependência de suas ações levam a um comportamento estratégico único permitindo à maximização conjunta de lucros.

Um aspecto importante do cartel é o seu gerenciamento, que deve se preocupar com três questões fundamentais: a alocação da produção entre os membros, a alocação do lucro do cartel entre os membros e o policiamento do acordo de cartel. ${ }^{5}$ Vale salientar que essas questões não são independentes entre si, daí a sua complexidade.

Em muitos países, a legislação interna não permite acordos colusivos, por isso, o cartel não pode ir ao tribunal exigir o cumprimento do acordo entre os membros. As atividades são escondidas para evitar perseguição. Os acordos colusivos entre países são permitidos (exemplo: OPEP), mas não são legalmente exigido o seu cumprimento. Como resultado, os acordos de cartéis deveriam ser sempre self-enforcing (auto cumprimento) e forward-looking e não envolver ameaças não críveis (BIERMAN; FERNANDEZ, 1998).

Os cartéis formais são aqueles em que as empresas estabelecem comunicação explícita ou contato direto, combinando preços ou regras de comportamento. De outro modo, quando a coordenação de preços ou ações é fruto da racionalidade econômica, as empresas seguem regras tácitas, que não foram combinadas explicitamente, ou seja, decorrentes da vivência na indústria e do aprendizado. Nesse caso, chama-se de cartéis tácitos, também conhecido na literatura econômica como "conluio tácito".

Nos casos de licitação pública, os acordos existentes entre licitantes tipifica-se também como cartel/conluio, conhecida como fraude em licitação pública. Esta consiste, simplesmente, do ponto de vista do direito antitruste, na coordenação entre empresas participantes de uma licitação pública, no sentido de prejudicar o objetivo do procedimento licitatório de obtenção de preços mais favoráveis para o licitante. Por exemplo, no caso de uma licitação de venda de um produto, as empresas podem agir de modo concertado para que se

5 Um bom exemplo da importância do policiamento do cumprimento do acordo, refere-se ao leilão de objetos onde, ex-ante, houve um conluio para baixar o preço reserva (o preço mínimo para fins venda). Neste caso, todos participam do leilão, mas nenhum apresenta oferta, uns ficam vigiando o outro. Ao leiloeiro resta cancelar ou baixar o preço reserva. 
determine qual delas apresentará o menor preço. Outra forma de fraudar esse tipo de procedimento é estabelecer um revezamento das empresas que irão vencer determinadas licitações ou ofertas públicas, pré-estabelecendo as ofertas que as empresas participantes e incluídas no esquema realizarão. ${ }^{6}$

Para o presente artigo, adota-se duas linhas de raciocínio sobre cartéis, primeiro cartel será sinônimo de conluio e segundo não haverá preocupação em distinguir entre conluio formal e tácito, pois conluio formal depende de contrato entre seus membros, mas um contrato que não tem eficácia legal também não faz muito sentido. No caso de conluio tácito será usado de uma forma geral representando qualquer acordo entre licitantes no que tange à combinação de estratégia de participação em licitações públicas com o sentido de obter vantagens (definir faixa de mercado, evitar entrada de concorrente, definir preço e obter excedente) ao arrepio da lei. ${ }^{7}$

Em termos de setor público, os conluios possuem configurações nas quais os preços combinados aparecem em pelo menos quatro variedades: fixação de preços de determinada proposta, divisão de uma proposta entre vários fornecedores, divisão de regiões geográficas entre fornecedores para gerar monopólios locais, e divisão dos órgãos do governo entre fornecedores novamente criando monopólios ou oligopólios (Ver KLITGAARD, 1994). Mas há de se observar que existem práticas colusivas no âmbito da administração pública que a divisão de mercado se ajusta apenas para objetos diferentes (pelo menos em termos de datas de licitação), visto que normalmente o parcelamento de um mesmo objeto é proibido pela Lei de Licitação.

Os indicadores de possíveis conluios são:

1. preços propostos maiores que os valores de mercado.

6 Existe caso de fraude, principalmente na modalidade convite, onde há apenas uma empresa e as outras duas somente existente no papel - contabilmente.

7 Pode ser encontrada uma definição de cartel como um acordo, tanto formal quanto tácito entre concorrentes, uma idéia que está presente na forma legal, mas que parece equivocada do ponto de vista econômico. Segundo Tirole, J. (1988): 'Colusão Tácita' não precisa envolver nenhuma 'colusão' no sentido legal, e particularmente envolve a não comunicação entre as partes. O acordo é referido como colusão tácita somente porque o resultado alcançado (em termos de conjunto de preços ou quantidades produzidas, por exemplo) pode ser bem parecido com os alcançados através da colusão explícita ou mesmo de um cartel oficial. Um melhor termo sob uma perspectiva legal deveria ser 'coordenação tácita'”). Importante notar, então, que a diferença básica entre cartel e o conluio tácito não está relacionada com seus resultados (desempenho em termos de preços e quantidades ofertadas), e sim, com o fato de que no conluio tácito não há comunicação direta entre os participantes, sendo que a conduta das firmas é conseqüência da racionalidade econômica dos agentes, que utilizam as características estruturais e instrumentos do mercado facilitadoras dessa prática. 
2. provas de que a mesma pessoa preparou todas as propostas.

3. padrão de rodízio entre concorrentes vencedores.

Como já mencionado acima, um conluio está sempre sob ameaça de seus lucros monopolistas serem atrativos para uma ou mais firmas entrarem ou romperem a formação, fazerem uma proposta inferior e embolsarem grandes lucros.

c) Aspectos econômicos e institucionais da licitação pública

Nas aquisições de bens e serviços, a entidade pública atua como um agente econômico qualquer, mas pelo fato de ser um grande comprador (em termos consolidado a administração pública brasileira faz aquisições anual de $\mathrm{R} \$ 300$ bilhões), ela impõe, de certa forma, as suas regras licitatórias que visam atender princípios constitucionais (publicidade, impessoalidade, legalidade, moralidade e eficiência) e possibilitar de forma isonômica a aquisição/contratação mais vantajosa para a administração pública à luz do que ela dispõe a pagar.

Durante a realização de um procedimento licitatório, quem decide se aceita ou não as condições dos licitantes é a entidade promotora do evento. Por isso mesmo, as normas licitatórias (Lei n ${ }^{\circ}$ 8.666/93 e Lei $\mathrm{n}^{\mathrm{O}}$ 10.520/02) indicam o caminho a ser, obrigatoriamente, seguido por todos os administradores públicos. Neste artigo a medida que for citado um instrumento ou procedimento constante da referida Lei, será apresentado em nota o significado de alguns deles. Contudo, cabe, a priori, referenciarmos os seguintes preceitos da Lei, em vista da sua similaridade com as condições seguidas pelos outros agentes da economia:

a) restrição orçamentária, visto que somente poderá haver licitação se houver orçamento detalhado em planilhas que expressem a composição de todos os seus custos unitários e previsão de recursos orçamentários que assegurem o pagamento das obrigações (ver artigos $7^{\circ}, 14^{\circ}$ e 40$)$.

b) as compras, sempre que possível, deverão submeter-se às condições de aquisição e pagamento semelhantes às do setor privado e balizar-se pelos preços praticados no âmbito dos órgãos e entidades da Administração Pública (art. 15). As principais modalidades de licitação são convite, tomada de preços, concorrência e pregão, sendo utilizado prepoderantemente o critério de menor preço para a escolha do vencedor do certame licitatório (A Lei ainda prever outros critérios de julgamento que são a técnica e preço e melhor técnica, mas que são pouco utilizadas). As modalidades são definidas de acordo com o valor da estimativa da licitação e/ou com base numa imposição regulamentar, no caso do pregão. Além disso, 
a concorrência pode ser usada independentemente do valor e a tomada de preços pode ser usada mesmo que o valor seja de convite. Segue abaixo quadro definindo como deve ser a escolha da modalidade da licitação, com base no valor estimado:

Quadro 1. Critério de escolha da modalidade licitatória

\begin{tabular}{|l|l|}
\hline \multicolumn{1}{|c|}{ Modalidade } & \multicolumn{1}{c|}{ Fator para escolha da modalidade } \\
\hline Concorrência & $\begin{array}{l}\text { - Obras/Serviços de Engenharia: }>\mathrm{R} \$ 1.500 .000,00 \\
- \text { Compras e outros serviços: }>\mathrm{R} \$ 650.000,00\end{array}$ \\
\hline Tomada de Preços & - Obras/Serviços de Engenharia: $>\mathrm{R} \$ 150.000,00 \mathrm{e}<\mathrm{R} \$ 1.500 .000,00$ \\
& - Compras e outros serviços: $>\mathrm{R} \$ 80.000,00 \mathrm{e}<\mathrm{R} \$ 650.000,00$ \\
\hline Convite & - Obras/Serviços de Engenharia: $>\mathrm{R} \$ 15.000,00 \mathrm{e}<\mathrm{R} \$ 150.000,00$ \\
& - Compras e outros serviços: $>\mathrm{R} \$ 8.000,00 \mathrm{e}<\mathrm{R} \$ 80.000,00$ \\
\hline Pregão & Preferencial sobre as outras modalidades. Ou seja, o Pregão é prioritário. \\
\hline
\end{tabular}

Um dos pilares da licitação eficiente consiste na estimativa do valor do objeto ou serviço licitado, pois ela dará sustentação ao processo de julgamento das propostas apresentadas. Essa estimativa não é divulgada para os licitantes, embora a Lei de Licitação, art. 40, inciso X, permite (mas não obriga) a divulgação do valor máximo que a administração está disposta a pagar. Surgem duas observações a esse respeito, primeiro o valor máximo não implica que seja o valor estimado, segundo a divulgação antecipada do valor máximo incentivaria a prática de cartel.

A priori, não divulgar o valor estimado da licitação gera incentivos para que os concorrentes apresentem suas propostas de preços verdadeiras (ou seja, aquela que efetivamente representa seus custos e a margem de remuneração adequada para o negócio), visto que todos correm o risco de perderem a licitação. Adiante será mostrado que, de fato, os licitantes experientes têm idéia do valor estimado, principalmente no caso de obras e serviços de engenharia, e o máximo que a administração está disposta a pagar.

Outro pilar econômico da licitação (no sentido da economia da informação) refere-se à divulgação do edital da licitação, que será de acordo com a modalidade. Quanto maior a ampliação da divulgação maior a possibilidade de ampliação da competividade e a obtenção de melhores preços. Mas não há uma garantia para isso, pois o jogo licitatório cria incentivos para que as empresas apresentem propostas infladas. Com isso, a divulgação somente tem eficácia se combinada com outras regras, tais como aquelas do pregão eletrônico, onde as informações são incompletas e imperfeitas. Vale salientar que nos jogos de informação incompleta, o jogador somente conhece o seu payoff, ou seja ele não detém toda a informação para escolher sua 
jogada e nos jogos de informação imperfeita os jogadores não sabem tudo que ocorreu antes do início da jogada, embora, para esse caso, eles conheçam o lance anterior.

Quadro 2. Formas de divulgação dos certames licitatórios

\begin{tabular}{|l|l|}
\hline Modalidade & Forma de Publicidade \\
\hline Concorrência & $\begin{array}{l}\text { Jornais de circulação municipal, estadual. } \\
\text { DOE (Estado e Município) }\end{array}$ \\
\hline Tomada de Preços & $\begin{array}{l}\text { Jornais de circulação municipal, estadual. } \\
\text { DOE (Estado e Município) }\end{array}$ \\
\hline Convite & Fixação em local apropriado e convite aos interessados. \\
\hline Pregão & $\begin{array}{l}\text { Presencial: } \\
<\mathrm{R} \$ 160,000,00: \text { DOU e Internet. } \\
>\mathrm{R} \$ 160.000,00 \text { e }<\mathrm{R} \$ 650.000,00: \text { DOU, Internet e jornal de } \\
\text { grande circulação local. } \\
>\mathrm{R} \$ 650.000,00: \text { DOU, Internet e Jornal de grande circulação } \\
\text { nacional ou regional. } \\
\text { Eletrônico: } \\
<\mathrm{R} \$ 650,000,00: \text { DOU e Internet. } \\
>\mathrm{R} \$ 650.000,00 \text { e }<\mathrm{R} \$ 1.300 .000,00: \text { DOU, Internet e jornal de } \\
\text { grande circulação. } \\
>\mathrm{R} \$ 1.300 .000,00: \mathrm{DOU}, \text { Internet e Jornal de grande circulação } \\
\text { nacional ou regional. }\end{array}$ \\
\hline
\end{tabular}

A principal etapa da fase externa da licitação trata-se do julgamento das propostas, onde a licitação será adjudicada para o licitante que apresentar o menor preço, no caso de empate ocorre o sorteio. A Lei, art. 43, inciso IV, combinado com art. 48, parágrafo $3^{\circ}$ e art. 24, inciso VII, prever que no caso de todas as propostas serem desclassificadas, por exemplo valor acima do que a administração está disposta a pagar, o prazo será reaberto, 8 dias úteis, para que os licitantes apresentem novas propostas. Mantidas as razões da desclassificação poderá a administração contratar diretamente com um dos licitantes ou com um que não tenha participado do certame. Também, será mostrado, por meio da teoria dos jogos, que essa prerrogativa não impede a prática de conluio.

Por fim, existe o pregão, criado pela Lei $n^{\circ} 10.520 / 2002$, que é a modalidade de licitação para aquisição de bens e serviços comuns (aqueles cujos padrões de desempenho e qualidade possam ser objetivamente definidos pelo edital, por meio de especificações usuais no mercado), independentemente do valor estimado da contratação, 
em que a disputa pelo fornecimento é feita por meio de propostas e lances na forma presencial ou eletrônica. É o inverso do leilão (por isso, o pregão é um tipo de leilão reverso) no qual o licitante vencedor é o que apresenta a maior proposta. As vantagens apresentadas por essa modalidade são transparência, aumento da competitividade, redução dos custos de aquisição, desburocratização e celeridade. A desvantagem do Pregão é a restrição legal de não poder ser usado para contratação de obras e alguns serviços de engenharia.

O pregão representa um avanço no combate às práticas de conluio, visto que no pregão eletrônico para bens/serviços, onde haja muitas empresas, torna-se difícil a articulação entre os licitantes, pois elas não sabem, em nenhuma fase, com quem estão disputando o certame e, como é divulgado e disputado via internet, não se tem idéia de onde é a empresa. Além disso, a fase de lances incentiva a empresa a reduzir os seus preços.

\section{Analisando os instrumentos da Lei de Licitação para evitar as práticas de conluio nas aquisições do setor público.}

Considerando que os agentes respondem a incentivos, então pode-se supor que a eficácia da procedimentos licitatórios depende da sua capacidade em criar incentivos para que os licitantes apresentem propostas verdadeiras. Vale ressaltar que uma proposta verdadeira é aquela que se iguala ao valor que o licitante pode realizar a obra e que lhe assegure a cobertura de todos os seus custos mais uma margem de remuneração compatível com sua atividade. Neste caso não há extração de todo excedente econômico. Os instrumentos que a Lei de Licitação dispõe para que os licitantes apresentem propostas verdadeiras são a ampla divulgação da licitação para ampliar a competividade, a não revelação dos preços estimados, a desclassificação de propostas elevadas e inexeqüiveis e a punição pela cobrança de sobrepreços. A seguir, analisa-se os instrumentos relativos à divulgação e à desclassificação das propostas, pois anteriormente foram analisados os efeitos da não revelação dos preços estimados e a punição pela cobrança de sobrepreços foge dos objetivos do trabalho, que teria que enfatizar os mecanismos da Lei $n^{\circ} 8.884 / 94$, que trata de antitrustes.

i) Ampla divulgação do edital de licitação no sentido de ampliar o número de participantes e a competividade.

Supondo que a divulgação aumente o número de participantes e com isso amplie a competição, há incentivo para uma empresa apresentar uma proposta verdadeira? 
Pela Lei das licitações, excluindo o pregão, cada licitante apresenta em envelope lacrado suas propostas em um único lance e aquela mais baixa é considerada a vencedora. Adaptando uma situação de Dixit e Nalebuff (1994), será mostrado o que ocorre numa licitação para uma obra de engenharia.

Quando da elaboração da proposta, um licitante calcula sua proposta em $\mathrm{R} \$ 10$ milhões. Ele não conhece os custos das outras licitantes, mas há razão para acreditar que estão entre $R \$ 5$ e $R \$ 10$ milhões. Uma proposta menor que os custos não é factível, não há como revisar os preços, por isso há probabilidade de inviabilizar o funcionamento da empresa, caso defina um valor abaixo de $R \$ 10$ milhões.

Então o licitante adotará uma estratégia com base nas seguintes condições: i) Supondo que A apresente uma proposta de R 11 milhões, mas ele espera que cinco entre dez propostas fiquem entre $\mathrm{R} \$ 7$ milhões e $\mathrm{R} \$ 10$ milhões, com isso, ele perde e nada adianta cobrar mais; ii) Quatro entre dez propostas sejam superiores a $R \$$ 11 milhões, assim ele poderia ganhar a licitação com uma proposta de $\mathrm{R} \$ 10$ milhões ou de $\mathrm{R} \$ 11$ milhões, sendo que com $\mathrm{R} \$ 11$ milhões ele teria um ganho adicional de $\mathrm{R} \$ 1$ milhão; iii) Há uma chance em dez de haver uma proposta concorrente entre $R \$ 10$ milhões e $R \$$ 11 milhões, neste caso inchar sua proposta significa perder a licitação. Mas sendo verdadeiro e apresentando $\mathrm{R} \$ 10$ milhões, o valor somente paga os custos e um ganho normal (remuneração), por isso, há motivos para apresentar uma proposta maior.

Diante dessas 3 possibilidades, há incentivos para não revelar sua verdadeira proposta e usar uma estratégia com preços superiores a $\mathrm{R} \$ 10$ milhões, ou seja, será uma proposta dominante. Assim pensarão todos os concorrentes e todos irão inflar seus preços.

Qual a solução para o caso, onde mentir é uma estratégia dominante. Seria adotar um formato de licitação, no qual incentivasse os licitantes falarem a verdade. Segundo, Dixit e Nalebuff (1994) deveria ser aplicada uma licitação com o formato de um leilão de segundo preço (Leilão de Vickrey), onde a proposta mais baixa venceria a licitação, mas o vencedor receberia o valor do segundo colocado. Voltando ao caso da licitação acima, se o licitante apresentar a proposta de $R \$ 10.000 .000,00$, ele receberia um valor acima de $R \$ 10.000 .000,00$, caso fosse vencedor. Sendo esse raciocínio implementado por todos, então todos apresentariam propostas verdadeiras e a mais baixa venceria, recebendo o valor da segunda colocada.

Entretanto, esse formato de julgamento não é permitido por lei e pareceria uma solução ineficiente para a administração pública. Veja que se todos licitantes inflam, como no caso anterior, a administração pública pagará um preço maior para a proposta vencedora, 
gerando um custo social (externalidade). Adotando o mecanismo do leilão de segundo preço, ele estaria apenas compensando, pagando ao vencedor a diferença entre a forma anterior de julgar a licitação e a nova pelo segundo preço.

Contudo, como se verifica, o resultado econômico pode ser o mesmo, dependendo do tamanho da compensação. Então, qual seria a motivação para o setor público adotar o leilão de segundo preço? Talvez o fato de não contrariar os princípios constitucionais da eficiência e moralidade e criar uma cultura de transparência nas licitações públicas, onde todos falam a verdade.

Por fim, cabe alertar que o fato da empresa não revelar o seu verdadeiro valor não implica em prática de conluio, representa apenas uma estratégia individual, independentemente de acordo de conluio.

ii) desclassificação de propostas elevadas e inexeqüíveis.

Para os empresários: a cada um é reservada uma estratégia dominante que é praticar o conluio, ${ }^{8}$ independentemente se há ou não intenção da comissão de licitação desclassificar as propostas. Para eles o difícil é formar e coordenar o conluio, feito isso, o conluio se justifica. Antes de se mostrar a ineficácia da sinalização da desclassificação das propostas, cabe verificar um caso onde a cooperação e a formação do conluio leva a resultados melhores que a não cooperação e não conluio. Para ver isso, deve-se simular o seguinte:

a) seja um processo licitatório na modalidade de tomada de preços instaurada por uma prefeitura para contratar uma empresa para execução de uma obra de engenharia. A estimativa da administração para o preço da obra não é divulgada.

b) pela experiência das empresas, elas sabem que os serviços podem ser realizados por $\mathrm{R} \$ 300.000,00$, por isso, também sabem que a estimativa da prefeitura deve girar em torno de $\mathrm{R} \$ 350.000,00$.

c) apenas duas empresas se cadastraram dentro do prazo (72 horas antes da abertura das propostas) e estão analisando a possibilidade de adotarem práticas de conluio para obter o maior excedente possível entre os custos efetivos da obra e o valor que a Prefeitura está disposta a pagar para sua realização.

d) sabe-se que devido aos órgãos de controle (tribunais de contas e Controladoria Geral da União) e ministério público, a prefeitura somente pode arriscar contratar a preços de até $\mathrm{R} \$ 400.000,00$ (em torno de $10 \%$ acima do valor estimado).

Analisando por meio de um jogo de conluio, representado na forma normal - ver matriz do jogo a seguir, tem-se que se a empresa

8 Mesmo sabendo se tratar de uma prática ilegal. O fato é que a falta de punição torna o valor esperado da empresa positivo. 
Y adota a prática de conluio e a empresa X não, apresentando uma proposta de $R \$ 400.000,00$, ela perderá a licitação pois a empresa $X$ não cumpriu o acordo. A empresa $\mathrm{X}$ apresentará uma proposta inferior a $\mathrm{R} \$ 400.000,00$, no caso $\mathrm{R} \$ 399.999,99$ para obter o máximo de excedente possível. O mesmo raciocínio vale no caso da empresa X adotar o conluio e a empresa Y não. Mas se houver o conluio, ou seja, ambas cooperarem o conluio extrairá todo excedente de $\mathrm{R} \$ 100.000$, o que permitirá dividi-lo igualmente para os dois e acordarem que a construção cabe a empresa $\mathrm{X}$ agora, para na próxima licitação, na mesma cidade ou em outra cidade, a empresa Y ser a vencedora. Vale ressaltar que há ganhos implícitos adicionais para o vencedor, pois na execução do contrato existe a possibilidade de redução dos custos e obtenção de algo mais - lícita ou ilicitamente. Os dois sabem desse ganho adicional, mas como dependem das ações de cada um, da passividade do contratante e as vezes esse ganho pode não ocorrer, os dois preferem não considerar esse ganho no acordo.

O Conluio seria o equilíbrio do jogo, chamado de Equilíbrio de Nash, (também é eficiente de pareto, tendo em vista que qualquer alteração dessa situação haverá perda para um ou para ambos), pois no caso de não cooperação nesse estágio (nessa licitação) por parte de um, na próxima licitação nenhum dos dois irá adotar prática de conluio, o que levaria os dois a cobrarem $R \$ 350.000,00,{ }^{9}$ levando a licitação ao sorteio. Com o sorteio o valor esperado do payoff de ambos seria de $R \$ 25.000$ (probabilidade de $50 \%$ vezes $R \$$ 50.000 ), o que seria menor que os $R \$ 50.000,00$ obtidos no caso de cooperação entre eles.

O Jogo do Conluio nas Licitações Públicas

\begin{tabular}{|c|l|l|l|}
\cline { 3 - 4 } \multicolumn{2}{c|}{} & \multicolumn{2}{c|}{ Empresa Y } \\
\hline \multirow{2}{*}{ Empresa X } & Conluio & Não Conluio \\
\cline { 2 - 4 } & Não conluio & $50.000 ; 50.000$ & $0 ; 99.000$ \\
\hline
\end{tabular}

Verificado a lógica de formar o conluio, parte-se para mostrar se a ameaça da comissão em desclassificar propostas tem efeito sobre a atuação do conluio.

9 A lógica do valor $\mathrm{R} \$ 350.000,00$ vem da teoria do ponto focal (escolha natural); haveria dois pontos focais $R \$ 300.000,00$ e $R \$ 350.000,00$, como $R \$ 350.000,00$ é maior, elas optariam por esse último valor, trabalhar com o primeiro valor seria muito complicado no caso da prefeitura não honrar com o cronograma de pagamentos. 
Normalmente se percebe nas aquisições e execução de contrato no setor público o seguinte: falhas nas estimativas dos valores licitados, fragilidade na fiscalização da execução dos contratos, poucas empresas dispostas a prestarem serviços para as prefeituras com população abaixo de 100.000 habitantes, devido às práticas irregulares e a dificuldade de recebimento dos valores contratados. Além disso, o mercado já é dividido e ocorre de tudo, empresas montam as propostas dos licitantes e há até subempreita informal para realização do objeto; o licitante vencedor aparece apenas para receber os recursos e dividir com o executor. Mesmo assim é plausível imaginar situações onde haja a possibilidade de existir uma comissão de licitação disposta a desclassificar as propostas consideradas elevadas e orientar o gestor a contratar diretamente sem licitação (com base no art. 24, inciso VII e art. 48 da Lei de Licitação).

Então, a administração pública lança o edital de tomada de preços no jornal de circulação regional para a contratação de empresa para execução de uma obra de engenharia. Há uma sinalização da Comissão de Licitação que irá desclassificar todas as propostas consideradas fora da regra de licitação, pois em licitação anterior foram desclassificadas todas as propostas e usou-se o art. 48 da Lei de Licitação para abertura de prazo para que todos os licitantes apresentassem novas propostas. $\mathrm{O}$ valor estimado pelo Administração não é divulgado, mas pela modalidade de licitação e os anexos do edital que trazem as especificações da obra é possível os licitantes terem uma idéia do valor estimado.

Com base no prazo estipulado pela Lei de Licitação, 3 empresas (X, Y e Z) são cadastradas para o certame, sendo que duas delas sempre participam de licitações naquela cidade e nos municípios próximos. Há um conluio não formalizado entre as duas empresas que aquela licitação seria da empresa $X$, pois em certame anterior venceu a empresa Y. A estrutura de capital das duas empresas são similares. A terceira empresa que se cadastrou no prazo regular quer entrar para participar da licitação, mas sabe que há um conluio entre as empresas X e Y, onde uma protege a outra e dividem o mercado.

Pela experiência das 3 empresas, elas sabem que os serviços podem ser realizados por $\mathrm{R} \$ 300.000,00$, mas apenas o conluio sabe que a estimativa da prefeitura deve girar em torno de $\mathrm{R} \$ 360.000,00$, isto é, há o uso de uma informação privada. Vale lembrar que por razões técnicas e interesses camuflados, que a comissão de licitação não conhecem, as estimativas da área técnica da prefeitura não são boas.

$\mathrm{Na}$ elaboração de sua proposta, a empresa $\mathrm{Z}$ define suas estratégias para disputar e vencer o certame. A sua estrutura de custos não 
permite que cobre menos que $\mathrm{R} \$ 300.000,00$, pois ela não conhece os fiscais de obras da prefeitura e os gestores financeiros para fins de obter vantagens compensatórias na execução do contrato com valor menor que este. Mas ela sabe que os arranjos compensatórios (material de segunda categoria, aditivo ao contrato para serviços que não serão realizados entre outros) na execução do contrato são possíveis para as empresas $\mathrm{X}$ e $\mathrm{Y}$. Ademais, ela sabe que se mergulhar nos preços, abaixo de $\mathrm{R} \$ 300.000,00$, há duas possibilidades: i) sua desclassificação, dependendo do valor estimado pela prefeitura e da manipulação proposital das propostas pelas empresas do conluio); ii) prestar garantias adicionais, caso fique $80 \%$ inferior ao valor da estimativa da prefeitura, o que aumentará os seus custos e o seu prejuízo. ${ }^{10}$

Então a estratégia da empresa $Z$ seria cobrar algo na faixa de $R \$ 300.000,00$ a $R \$ 330.000,00$, o que provavelmente lhe tornaria vencedora do certame. $\mathrm{O}$ conluio sabe que a empresa $\mathrm{Z}$ irá "mergulhar", abaixo de $R \$ 300.000,00$, ou cobrar algo próximo de $R \$$ 330.000 , o que inviabilizaria a sua proposta de obter o máximo possível da prefeitura, que seria algo em torno de $R \$ 40.000,00$ acima do valor estimado, superior a isso, cresce a probabilidade dos órgãos de controle ressalvar a prefeitura ou as propostas serem desclassificadas e a comissão reabrir o prazo de oito dias úteis para reformulação das propostas e, assim, as táticas de conluio das duas empresas serem reveladas de fato para a empresa $Z$.

Em vista disso, o conluio irá dividir o excedente com a empresa $Z$, mas a empresa $Z$ só aceitará algo próximo de $R \$ 30.000,00$ para não entrar no processo licitatório, que seria a diferença entre os seus custos e a margem de lucro anormal que ela poderia obter.

Nos termos de jogo na forma normal, verifica-se a situação apresentada na matriz de payoff a seguir, onde se a empresa $Z$ entra ela pode obter um payoff de $R \$ 30.000,00$ (diferença entre o seu preço verdadeiro e o que a administração aceitaria em pagar). $\mathrm{O}$ conluio nada obteria. Mas a empresa $\mathrm{Z}$ teria que mobilizar toda uma estrutura

10 De acordo com o art. 48, inciso II, da Lei no 8.666/93, são manifestadamente inexeqüíveis, no caso de licitações de menor preço para obras e serviços de engenharia, as propostas cujos valores sejam inferiores a $70 \%$ (setenta por cento) do menor dos seguintes valores:

a) média aritmética dos valores das propostas superiores a 50\% (cinqüenta por cento) do valor orçado pela administração, ou

b) valor orçado pela administração.

- Os licitantes cujo valor global da proposta for inferior a $80 \%$ (oitenta por cento) do menor valor a que se referem as duas opções acima, será exigida, para a assinatura do contrato, prestação de garantia adicional igual a diferença entre o valor resultante dos parâmetros citados e o valor da correspondente proposta. 
para executar o contrato e correria o risco da prefeitura não cumprir o cronograma de pagamento. Se o conluio entra e a empresa $Z$ não entra, em vista da proposta do conluio em repartir o excedente, ela ganhará os $\mathrm{R} \$ 30.000,00$ e não terá nenhum custo de mobilização ou risco que é todo do conluio. Assim, o equilíbrio do jogo será (não entra, entra), ficando o conluio com o excedente de $R \$ 70.000,00$, para repartir entre as duas empresas $\mathrm{X}$ e $\mathrm{Y}$ e a empresa $\mathrm{Z}$ com $\mathrm{R} \$$ $30.000,00$. Vale salientar que o conluio não terá incentivo para apresentar uma proposta menor que $R \$ 400.000,00$, pois ele sabe da intenção da prefeitura pagar esse valor, bem como do fato que o valor da proposta da empresa Z será próximo de $R \$ 300.000,00$, por isso, deixar a empresa participar representa um risco muito grande.

Jogo de Barreira em Licitação Pública

\begin{tabular}{|l|l|l|l|}
\cline { 3 - 4 } \multicolumn{2}{c|}{} & \multicolumn{2}{c|}{ Conluio } \\
\cline { 3 - 4 } \multicolumn{2}{c|}{ Entra } & Não entra \\
\hline \multirow{2}{*}{ Empresa Z } & Entra & $30.000 ; 0$ & $30.000 ; 0$ \\
\cline { 2 - 4 } & Não entra & $30.000 ; 70.000$ & $0 ; 0$ \\
\hline
\end{tabular}

Como se verifica, a ameaça de desclassificar pouco ajuda no processo, pois os valores serão os mesmos, o que há é uma redução dos ganhos do conluio, pois este terá que ofertar algo para os entrantes ficarem fora.

Diante disso, pode-se pensar que a solução seria ampliar o máximo a competividade para tornar a repartição do excedente entre as empresas muito pequena a ponto de não ser possível evitar a entrada das empresas, entretanto, não é muito provável a ampliação da competividade devido ao baixo valor envolvido e outras restrições econômicas para as empresas (custos de localização e mobilização, que não se diluem facilmente nos custos variáveis).

$\mathrm{E}$ se os valores orçados fossem menores, sendo no caso um convite e não uma tomada de preços, como evitar o conluio? A situação seria a mesma. Como já dito acima, não há como convidar muitas empresas a ponto de tornar inviável a repartição do excedente (diferença entre valor dos custos efetivos da obra e o valor cobrado pelo vencedor), além disso, haveria estímulo para o surgimento de empresas fabricadas somente para completar o número mínimo de 3 licitantes exigidos pela legislação.

Logicamente, as soluções de cartéis não são estáveis, principalmente quando não há acordos formalizados e punições críveis. Por isso, haverá sempre estímulo para uma empresa do conluio não 
cumprir o trato e apresentar uma proposta dentro das margens da estimativa e vencer a licitação, mas isso somente ocorrerá quando houver uma disputa direta, ou seja, no caso de existirem apenas duas empresas disputando a tomada de preços ou uma concorrência, a entrada de uma ou duas empresas adicionalmente irá estimular a prática de conluio.

E a modalidade Pregão está imune às práticas de conluio?

Inicialmente, vale lembrar que o pregão não se aplica às obras e serviços de engenharia, que representam uma fatia considerável dos gastos públicos. Mas pode-se, resumidamente, analisar duas situações: pregão presencial com muitas empresas e um pregão eletrônico com muitas empresas, ou seja, a divulgação surtindo efeito.

No pregão presencial com muitas empresas participantes, após a abertura das propostas, há uma faixa de corte $^{11}$ e pode ocorrer um limite máximo de empresas participantes dos lances, onde todos os concorrentes se conhecem. Não é permitido o acordo entre as empresas classificadas para os lances, mas nada garante que não tenha havido acordo, visto que a formação do conluio é uma etapa ex ante ao certame, assim as empresas mantém a divisão do mercado. Além disso, pode facilitar os objetivos do conluio, haja vista que, quando da ocorrência dos lances, podem ocorrer duas situações:

1. se forem 3 empresas duas do conluio e uma terceira não. As duas podem manipular a fase de lance;

2. se todas forem participantes do conluio, a redução dos preços via lance pode não ser significativa.

Para o caso do pregão eletrônico, não há como saber quem são os licitantes que estão apresentando lances seqüenciais e a única informação comum é o valor do lance imediatamente anterior. Neste jogo de informação incompleta, a estratégia dominante é baixar o valor até onde for possível cobrir os custos e não sacrificar a rentabilidade. Além disso, a amplitude da divulgação e da participação via internet permite que empresas de diversas localidades participem do certame, o que torna difícil a prática de formação de conluio, devido à dificuldade de coordenação e comunicação entre as empresas. Por isso, no pregão eletrônico com a participação de muitas empresas a probabilidade de conluio fica bastante reduzida.

Com uma simulação bastante simples, verifica-se a seguir se o pregão eletrônico é um mecanismo adequado para fazer o licitante revelar sua informação privada: a administração pública instaura

11 De acordo com o art. $4^{\circ}$, inciso VIII e IX, os lances serão dados pelas empresas que apresentaram propostas iniciais de até $10 \%$ superior a menor proposta. No caso desse critério não permitir um número mínimo de 3 licitantes, abre-se para aqueles, no máximo 3 , que apresentaram as melhores propostas. 
um pregão eletrônico para aquisição de produto na forma da Lei. O licitante 1 na elaboração da sua proposta sabe que a menor proposta terá o direito de iniciar os lances no sistema eletrônico, desde que ela não seja inexequível (muito abaixo do valor estimado da licitação, que somente o pregoeiro conhece), com isso, ele tem incentivo, estratégico, para apresentar uma proposta próxima a sua valorização do bem/serviço, pois a competividade na fase dos lances é que irá reduzir o desvio entre a valoração verdadeira e a que pode gerar excedente. Esse raciocínio será seguido pelos outros licitantes.

$\mathrm{Na}$ fase de lance, supondo que o conluio não exista, o licitante 2, supondo também que ele foi classificado, dará um lance para cobrir a proposta de valor menor apresentada pelo licitante 1, que ofertou a menor proposta inicial, já sabendo que ele se trata de um licitante do tipo que pretende apresentar uma proposta que se iguala a sua valorização do produto e não irá gerar para ele lucro anormal, por isso, o licitante 2 baixará a proposta caso ela não seja inferior a sua proposta verdadeira. Assim os outros farão o mesmo (e sucessivamente), deixando a disputa quando o lance imediatamente anterior for inferior a sua valorização verdadeira.

Então, a disputa ocorrerá até que o valor do último lance seja igual ao valor da proposta verdadeira, principalmente se houver muitos licitantes concorrendo neste estágio. Se o valor do último lance estiver de acordo com o valor estimado ${ }^{12}$ pela administração, haverá a adjudicação da licitação, mostrando que o mecanismo foi capaz de fazer os licitantes revelarem seus tipos e falarem a verdade (chamado na teoria de mecanismo de incentivo compatível).

Se a proposta final estiver acima da estimativa da administração, poderá o pregoeiro negociar com o licitante que apresentou a proposta mais baixa para enfim obter a proposta mais vantajosa para a administração (um tipo de teste ao mecanismo direto usado acima, em que pede ao licitante que revele sua informação privada), caso o licitante aceite baixar ainda mais, ele irá operar com prejuízo e buscará ao longo da execução do contrato compensar esse prejuízo com algum artifício ilegal ou renunciará ao contrato. ${ }^{13}$ Se não baixar,

$12 \mathrm{O}$ valor estimado não necessariamente é o preço reserva, pois a administração aceita um valor acima do estimado, mas esse adicional não pode ser significativo a ponto de gerar muitos esforços para sua complementação orçamentária. Para valores baixos situa-se em torno de $10 \%$, mas para valores elevados não pode passar de $5 \%$.

13 Poderia parecer que o caso seria simétrico a conhecida "maldição dos vencedores" que ocorre nos leilões, onde tende os vencedores a pagarem um preço superior a sua avaliação, devido à concorrência embutida no mecanismo do leilão. Mas no caso de pregão é preferível que a administração pública não extraia excedente do vendedor, pois será uma boa sinalização de futuras práticas indevidas na execução do contrato. 
a administração irá reformular sua estimativa e abrir novo processo de licitação. Como não houve conluio e participaram muitos concorrentes, o fato do insucesso da licitação não se deve ao mecanismo usado, mas a possíveis falhas na estimativa ou nas especificações do produto.

Por fim, vale salientar que, com poucas empresas participando dos pregões presenciais e eletrônicos, principalmente se for decorrente de restrição de mercado e elevados custos de entrada (custos de localização, mobilização, transporte...), a probabilidade de práticas de conluio são razoáveis para manter mercado ou dividi-lo. Um bom exemplo ocorre na área de contratação de serviços de vigilância armada e limpeza e conservação, onde as empresas de um estado não costumam disputar mercado com a de outro estado (talvez um acordo entre os sindicatos estaduais). Neste caso, há um tipo de conluio tácito no qual a ampla divulgação não é suficiente para atrair empresas que tornem os lances informações privadas (um jogo com informações incompletas). ${ }^{14}$

\section{Considerações Finais}

Com base na teoria dos jogos, verificou-se que os incentivos econômicos vislumbrados pelos agentes, incluindo os funcionários públicos que gerenciam o processo licitatório, e a limitada eficácia dos instrumentos licitatórios relativos aos procedimentos de divulgação, julgamento e desclassificação das propostas não evitam a práticas de conluio nas aquisições do setor público, exceto no pregão eletrônico com muitos participantes, onde a probabilidade de práticas de conluio são baixas, pois prevalece uma situação de informações incompletas, tais como o não conhecimento prévio dos licitantes em nenhuma fase dos lances e a amplitude geográfica dos participantes.

Contudo, as práticas de conluio não estão fora do controle da administração pública, visto que é sua competência exigir que as áreas técnicas realizem estimativas dos valores orçados de forma a evitar pagamento de excedentes, com isso, o contrato somente é assinado nessa margem, onde não há excedente para a divisão entre as empresas do conluio. Além disso, pode-se citar outros aspectos que deveriam ser trabalhados para a redução das práticas de conluio, quais sejam:

14 Um caso recente ilustra esse ponto: "O representante do Ministério Público Federal (MPF) no Conselho Administrativo de Defesa Econômica (Cade), pediu a condenação de 19 empresas de vigilância do Rio Grande do Sul e seus dirigentes, além do Sindicato das Empresas de Segurança Privada (Sindesp) e da Associação das Empresas de Vigilância do estado (Assevirgs) por formação de cartel”. Fonte: site www.mpf.gov.br, Informe de 30/07/07. 
a) melhoria da percepção política da administração pública realizadora do evento e de sua reputação, no sentido de ser possível executar um contrato e o cronograma de pagamento ser cumprido;

b) ampliação da competitividade via divulgação do edital na internet;

c) permissão do uso da modalidade de pregão para contrato de obras e serviços de engenharia possíveis de serem caracterizado de forma comum e padronizada;

d) atuação agressiva da polícia, ministério público, controle interno e externo e do poder judiciário na aplicação da Lei de Licitação e da Lei Antitruste no que tange às práticas de cartel;

e) gerenciamento do contrato via monitoramento dos serviços realizados, com atuação adequada dos fiscais dos contratos.

\section{Referências Bibliográficas}

BIERMAM, H. S.; FERNANDEZ, L. Game Theory - with Economic Applications. AddisonWesley Publishing Company, 1998.

DIXIT, A. K.; NALEBUFF, B. J. Pensando Estrategicamente: a vantagem competitiva nos negócios, na política e no dia-a-dia. São Paulo: Atlas, 1994.

FERNANDES, J. U. J. A licitação e os Cartéis. Disponível em: <www.escritorioonline.com.br>. Acesso em: 16/01/01

FLORES, G. A. Cartel: teoria econômica e a prática antitruste no Brasil. 2006. Tese de Mestrado, UFF/RJ.

GIBBONS, R. Game Theory For Applied Economists. Princeton University Press, 1992.

KLITGARD, R. A Corrupção Sob Controle. Rio de Janeiro: Jorge Zahar Ed., 1994.

LEVITT, S. D.; DUBNER, S. J. Freakonomics: o lado oculto e inesperado de tudo que nos afeta. Rio de Janeiro: Editora Campus, 2005.

MAS-COLLEL, A.; WHINSTON, M.D.; GREEN, J. R. Microeconomic Theory. New York: Oxford University Press, 1995.

PINDICK, R. S.; RUBINFELD, D. L. Microeconomia. São Paulo: 5. ed., Prentice Hall. 2002.

SILVA, G. P. Os Cártéis, a Licitação e a Teoria dos Jogos. Disponível em: <http// jus2.uol.com.br/doutrina/texto.asp?id=1980>.

TIROLE, J. The Theory of Industrial Organization. Cambridge: MIT Press, 1988.

VARIAN, H. R. Intermediate Microeconomics: a Modern Approach. WW Norton $\mathcal{E}$ Company. Fourth Edition. 1996.

LEGISLAÇÃO BRASILEIRA. Disponível em: http// www.planalto.gov.br. 